\title{
FASCICULATE KLEOPATRINID CORALS FROM THE BASHKIRIAN (LATE CARBONIFEROUS) OF SARDAR FORMATION (OZBAK-KUH MOUNTAINS, EAST-CENTRAL IRAN)
}

\author{
MAHDI BADPA \\ Department of Geology, Faculty of Science, Ferdowsi University of Mashhad, Mashhad, Iran. \\ mahdibadpa110@gmail.com \\ EDOUARD POTY \\ Paléontologie animale et humaine, Département de Géologie, Université de Liège, Bât.B18, Allée du 6 Août, \\ Sart Tilman, 4000-Liège, Belgium.e.poty@ulg.ac.be
}

\author{
ALIREZA ASHOURI \\ Department of Geology, Faculty of Science, Ferdowsi University of Mashhad, Mashhad, Iran. \\ ashouri@um.ac.ir
}

KAVEH KHAKSAR

Department of Water \& Soil, Imam Khomeini High Education Center, Institute of Scientific Applied Higher Education of Jihad-e-Agriculture, Karaj, Iran.kavehkhaksar@gmail.com

\begin{abstract}
In the East-Central Iran, the Sardar Formation (upper Visean-Moscovian) consists of shallow-water limestone with intercalations of shale containing rugose corals, tabulate corals and brachiopods. Ten sections were sampled in the Ozbak-kuh Mountains, from north to south. Among the rugose corals, an assemblage of fasciculate Kleopatrinidae has been collected. The latter contains the species: Paraheritschioides antoni antoni, P. antoni minor, P. gracilis and two new species for the genera Fomichevella and Heintzella. Heintzella is described from Iran for the first time. However, its age, as determined by conodonts and foraminifers, is early to middle Bashkirian (early late Carboniferous). The most similar, time-equivalent faunal associations are that of the Ellesmere Island, Sverdrup Basin in Arctic Canada, Alexander terrane and Brooks Range in southeastern Alaska and eastern Klamath terrane in northern California, where similar tropical warm water conditions have been identified during the Bashkirian in the northern hemisphere. During these times central Iran block and Northern provinces, characterized by a dominant carbonate facies and more diversified colonial coral faunas.
\end{abstract}

Key words: Iran, Ozbak-kuh, Sardar, Bashkirian, rugose corals.

RESUMO - A Formação Sardar (Viseano superior-Moscoviano) no Irã Central-Leste é caracterizada por calcários de ambientes pouco profundos com intercalações de folhelhos que contêm corais rugosos, tabulados e braquiópodes. Foram estudadas dez amostras das montanhas Ozbak-kuh, de norte a sul. Entre os corais rugosos foi amostrada uma associação de Kleopatrinidae fasciculados, que contém as espécies Paraheritschioides antoni antoni, P. antoni minor, P. gracilis e duas novas espécies novas para os gêneros Fomichevella e Heintzella. O gênero Heintzella é descrito pela primeira vez para o Irã. Contudo, a sua idade, determinada por conodontes e foraminíferos, é Bashkiriano inicial-médio (Neocarbonífero). As associações faunísticas contemporâneas mais semelhantes são as da Ilha de Ellesmere, bacia Sverdrup no Canadá Ártico, Terreno Alexander e Cordilheira Brooks no sudeste de Alasca, e o Terreno Klamath mais a leste na Califórnia setentrional, onde condições de águas quentes tropicais foram identificadas durante o Bashkiriano no hemisfério norte. O bloco central iraniano e as provincias setentrionais, durante este tempo, foram caracterizadas por facies calcárias dominantes e faunas coralinas coloniais diversificadas.

Palavras-chave: Iran, Ozbak-kuh, Sardar, Bashkiriano, corais rugosos. 


\section{INTRODUCTION}

The rugose corals suffered an important extinction at the Visean-Serpukhovian boundary (Dubatolov \& Vassiljuk, 1980; Fedorowski, 1981). Most families of the Visean, however, are represented in the Serpukhovian by several long-ranging genera. The end of the Mississippian (end of Serpukhovian) is characterized by a progressive impoverishment of the marine fauna, particularly coral faunas (Fedorowski, 1981; Kossovaya, 1996, 2002), and leading to the extinction of many groups. The Bashkirian recorded the recovery of the rugose corals with the first re-diversification of corals, mainly from solitary species that survived the Serpukhovian extinctions (Fedorowski, 1981; Kossovaya, 1996). The genera are well documented in the Ural Mts and Moscow Basin (Ogar, 1985, 1990; Kossovaya, 1996, 2002), Donets Basin (Fedorowski, 2009a,b, Fedorowski \& Vassiljuk 2011, Fedorowski \& Ogar, 2013), North America (Armstrong, 1972; Sando, 1985; Stevens, 2012; Fedorowski et al., 2014a,b) and China (Wu \& Zhao, 1989; Zhang et al., 2009, 2010). However, they are poorly known in time-equivalent assemblages from the southern Tethys from northern Africa (Semenoff-Tian-Chansky, 1974; Rodriguez et al., 2013) and
East central Iran (Flügel, 1974, 1975, 1994). The present study aims to document the Bashkirian fasciculate klaopatrinid rugose corals from east-central Iran.

The oldest report about the Bashkirian coral from Iran is that of Flügel $(1974,1975,1994)$, who described some solitary and colonial forms in the Ozbakh Kuh Mountains. Badpa et al. (2014) conducted preliminary studies in the same area in order to revise Flügel's fauna and they collected complementary material. The purpose of this paper is the description and illustration of the Bashkirian fasciculate kleopatrinid rugose corals and also comparison of these faunas to those from America and Eurasia.

\section{LOCATION OF THE KEY SECTIONS}

The Ozbak-kuh Mountains are located approximately 140 $\mathrm{km}$ north of Tabas city (east-central of Iran) (Figure 1). There are several complete Carboniferous outcrops in the central and southern parts of these mountains (Figures 2,3). The Zaladu Section (locality 1) is situated in the Eastern limb of the Zaladu syncline with $10 \mathrm{~km}$ length, located on the northern side of the Zaladu Valley at coordinates of N34 $39^{\prime} 42^{\prime \prime}$ and E57 $08^{\circ} 48^{\prime \prime}$. This succession is the most complete Carboniferous exposure

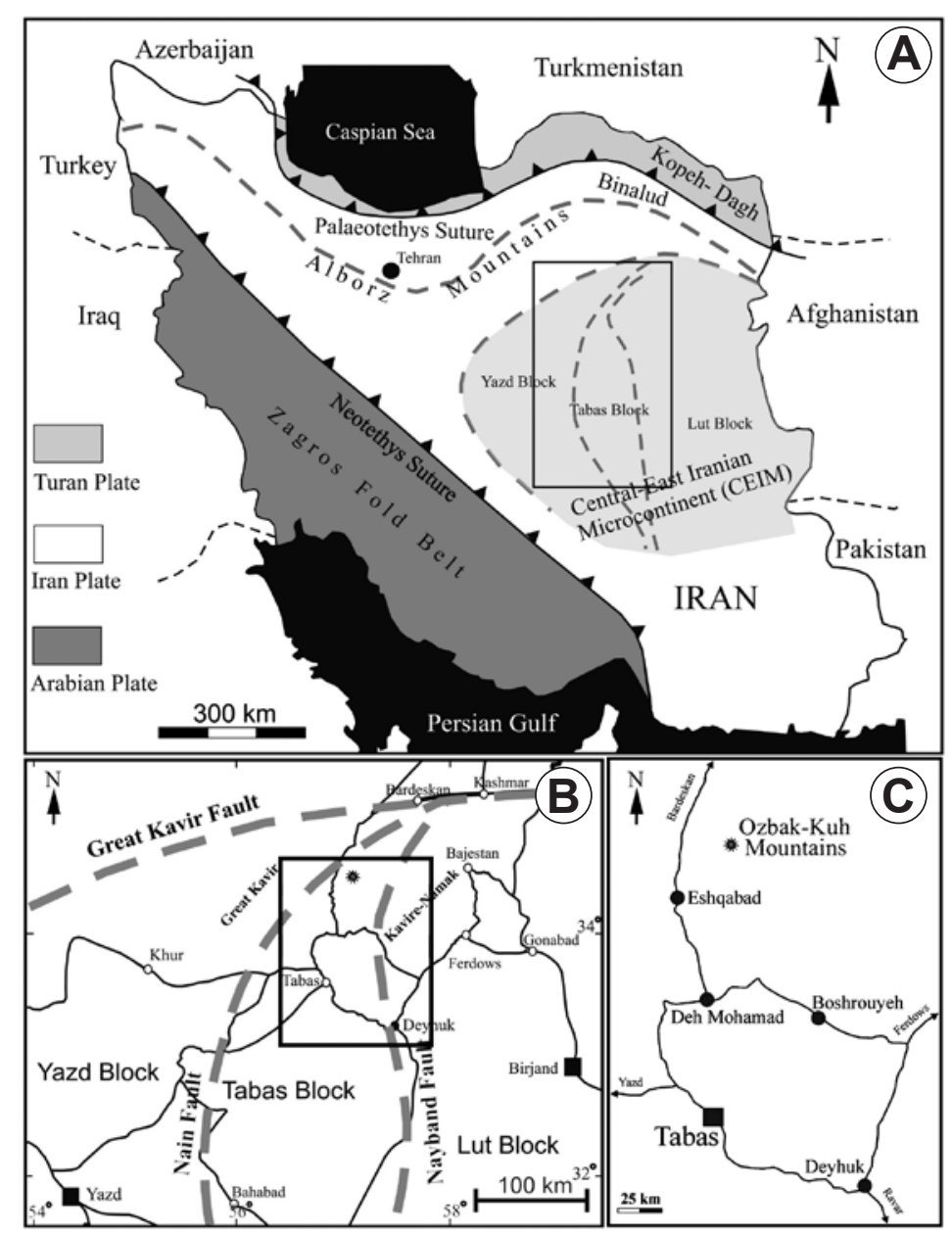

Figure 1. Location map of the study area and measured stratigraphic section in East Central Iran. A, map of present-day of Iran showing the geographical domains as well as the main sutures and tectonic structures of the Iran Plate. B, close-up view of white square, East-Central Iran (modified from Wilmsen et al., 2010). C, close-up view of rectangular area in B, with the location of study area in north Tabas. 

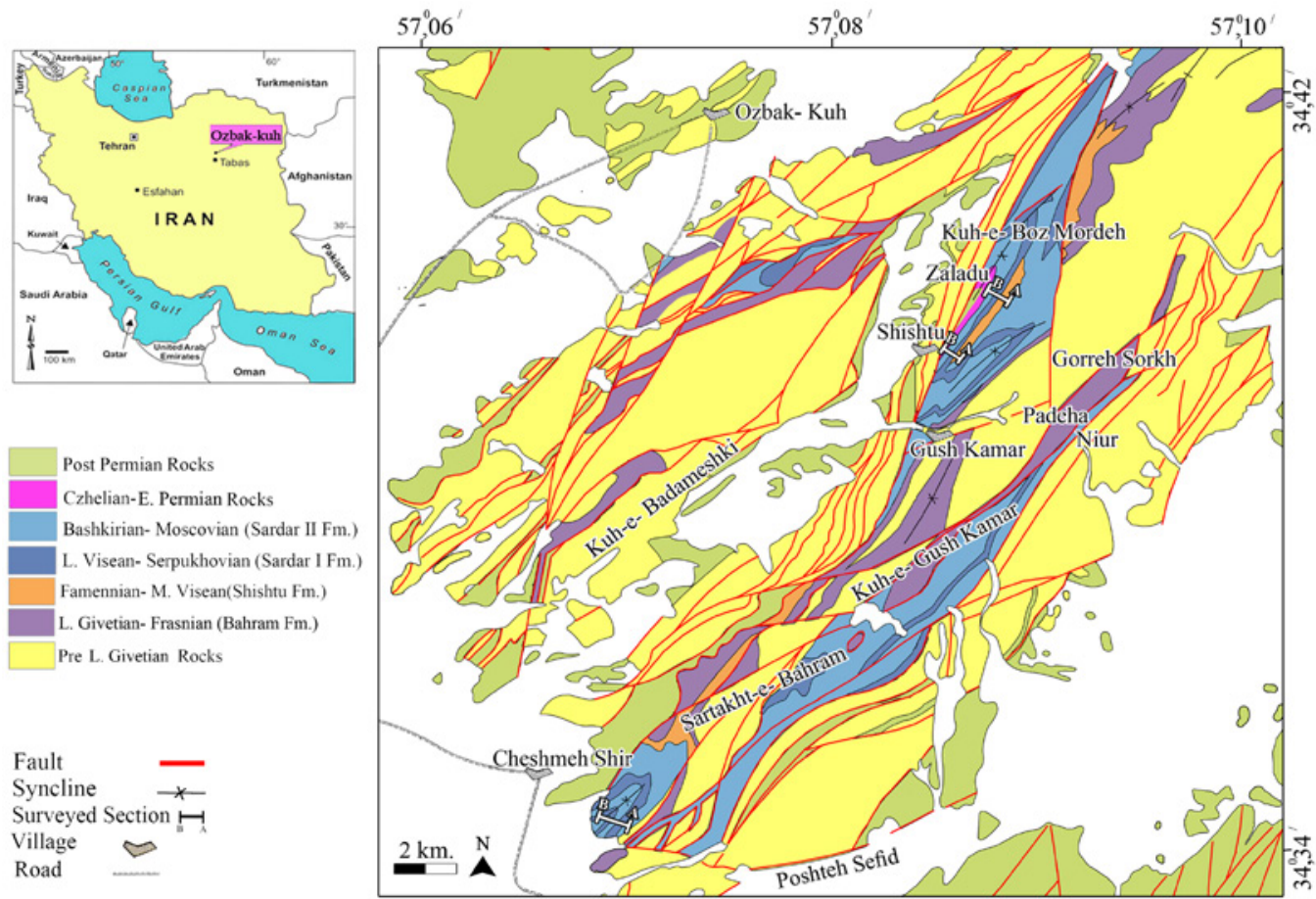

Figure 2. Geological location of studied area in the Ozbak-kuh Mouantains (modified from Ruttner et al., 1970).

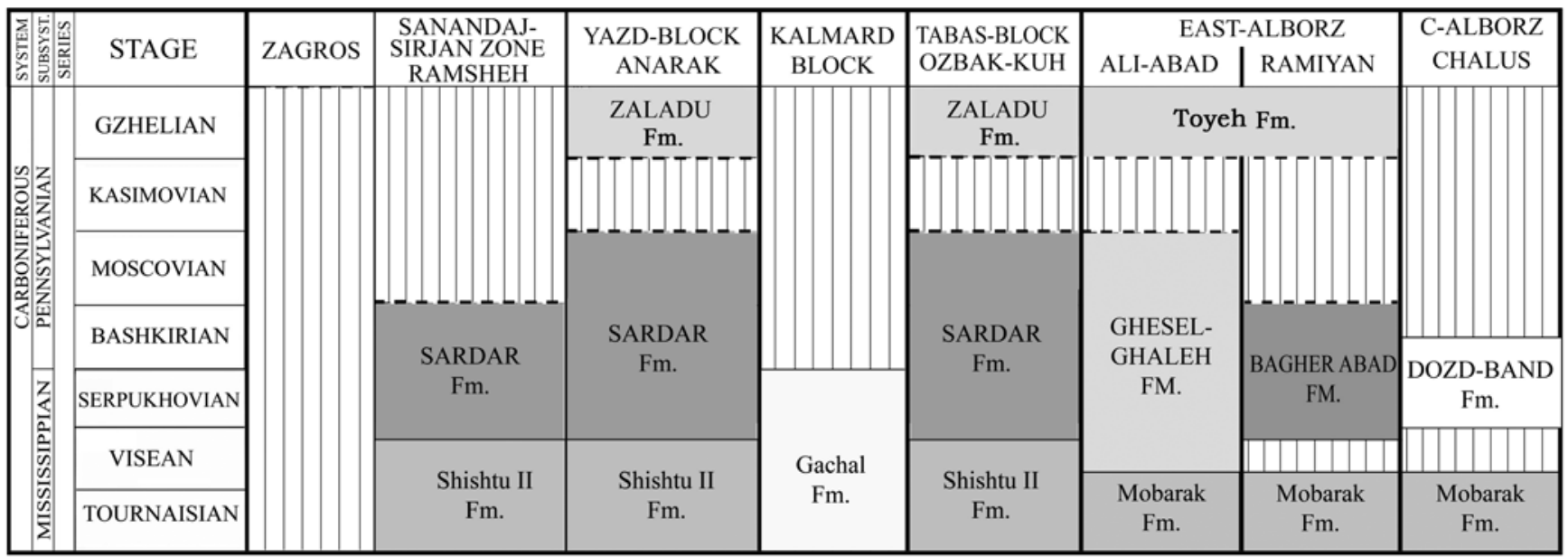

Figure 3. Synoptic chart of the Carboniferous formations of Iran. Ramsheh (Boncheva et al., 2007); Anarak (Leven \& Gorgij, 2006, 2011); Kalmard Block (Wendt et al., 2002, 2005; Aghabanati, 1977, 2009); Ozbak-kuh Mountains (Leven \& Gorgij, 2006, Sohrabi, 2005); East Alborz (Jenny et al., 1978, Jenny \& Stampfli, 1978; Brunet et al., 2009); central Alborz (Aghabanati, 2004, 2009; Brunet et al., 2009).

in the Ozbak-kuh Mountains. The other studied sections are the Zaladu Valley sections (localities 2, 3), Zaladu II (locality 4), Shishtu (locality 5), and Tangal-e-zireh sections (locality 6 ), situated in the middle parts of these mountains N343' $40^{\prime \prime}$ and E57 $08^{\prime} 38^{\prime \prime}$. The Cheshmeh-Shir sections (localities A-D), are located on the southern part of the Ozbak-kuh, situated in a syncline between coordination of N34 $33^{\prime} 30^{\prime \prime}$,

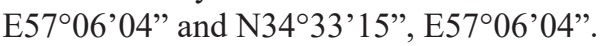

\section{GEOLOGIC SETTING}

The Ozbak-kuh Mountains are located in the northern part of the Tabas Block (Figure 1), (Stöcklin et al., 1965; Wendt et al., 2002, 2005; Brunet et al., 2009), which once was a failed rift basin related to the southern part of Paleotethys margin (Bagheri \& Stampfli, 2008; Lasemi, 2001; Scotese \& Langford, 1995; Stampfli \& Pillevuit, 1993; Sengor, 1984). The Carboniferous strata are represented by a thick succession consisting of the Shishtu (Famennian-middle Visean), Sardar (late Visean-late Moscovian), and Zaladu formations (early Gzhelian-middle Asselian), (Figure 2). The stratigraphic and sedimentological settings of the Ozbak-kuh area (Figures 2,3) were studied by Weddige (1984); Flügel (1994), Leven et al. (2006), Sohrabi (2005), Badpa et al. (2011, 2014), and Khanehbad (2012). The latter concluded that the carbonate rocks were deposited along a shallow-water homoclinal ramp.

The Sardar Formation is about $280 \mathrm{~m}$ thick (Figure 4). The formation covers the shales and limestones of the Shishtu 


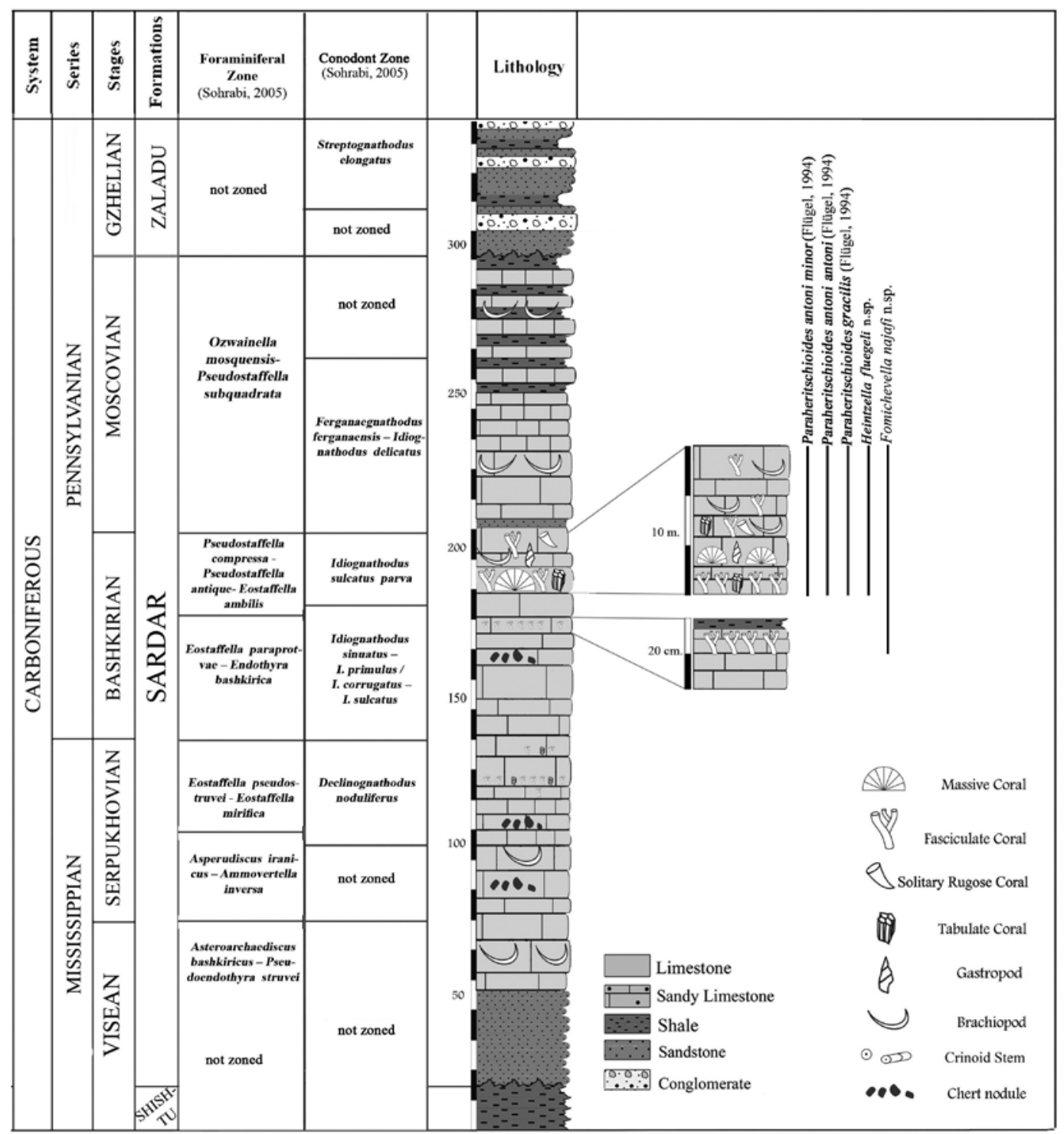

Figure 4. Generalized stratigraphical log of the Carboniferous succession in the Zaladu outcrop with the approximate position of the fossiliferous horizons and stratigraphic distribution of the rugose coral species.

Formation and is overlaid by the Zaladu Formation (Figures 2,4). Lithologically, the Sardar Formation can be divided into three parts. The lower part consists of about $30 \mathrm{~m}$ of sandstone (late Visean), the middle part consists of limestone with intercalations of shale (late Visean-Bashkirian) and the upper part consists of intercalations of limestone, shale, and sandstone (Moscovian).

\section{CORAL HORIZONS}

The studied corals were collected from two horizons in the middle part of the Sardar Formation (Figure 4). The lower horizon $(\sim 10 \mathrm{~cm}$ thick) is situated $167 \mathrm{~m}$ from the base of the formation. It yields only one genus of fasciculate rugose coral (Fomichevella). The matrix, embracing colonies is bioclastic wackestone. Study of the microfacies shows that they were formed in a lagoon of a shallow marine environment (Khanehbad, 2012).
Sohrabi (2005) studied the conodonts and foraminiferal assemblages in the Zaladu stratigraphic section and she indicated the early Bashkirian age for the mentioned horizon. It spans Eostaffella paraprotvae-Endothyra bashkirica foraminiferal zone and Idiognathoides sinuatus, Idiognathoides primulus-Idiognathoides corrugnatusIdiognathoides sulcatus conodont zone.

The upper horizon contains bundle of several fossiliferous limestone layers across an unit 5-10 m thick (173 m above the base of the formation). It yielded assemblages of fasciculate (Fomichevella, Heintzella, Paraheritschioides, Heritschioides, Opiphyllum), cerioid rugose (Minatoa, Klepatrina) and tabulate corals (Multithecopora, Michelinia). The matrix is a dominantly bioclastic wackestone-packstone. The limestones of this horizon contain brachiopods, gastropods, crinoids, and bryozoan remains. Study of the microfacies has shown that they were precipitated in a lagoon 
to open marine of a shallow marine carbonate ramp platform environment (Khanehbad, 2012).

Conodonts and foraminiferal assemblages (Sohrabi, 2005) indicated a middle Bashkirian age for this horizon. It spans Pseudostaffella compressa, P. antique, Eostaffella ambilis foraminiferal zone and Idiognathoides sulcatus parva conodont zone (Figure 4).

\section{SYSTEMATIC PALEONTOLOGY}

The newly collected material is housed in the museum of the Ferdowsi University of Mashhad, Iran. The terminology used in this paper follows Hill (1981) with some additions by Fedorowski et al. (2007).

Subclass RUGOSA Milne-Edwards \& Haime, 1850 Order STAURIIDA Verrill, 1865

Family KLEOPATRINIDAE Fedorowski, Bamber \& Stevens, 2007

Fomichevella Fedorowski, 1975
Type species. Campophyllum hoeli Holtedahl, 1913, Upper Carboniferous, base of Fusulina Limestone, west of Green Harbour, Vestspitsbergen.

Diagnosis. Fasciculate Kleopatrinidae with axial structure weakly developed in immature growth stages or entirely absent; cardinal septum shortened, in open cardinal fossula; lonsdaleoid dissepiments rare; tabularium biform where minor septa cross dissepimentarium (Fedorowski et al., 2007).

\section{Fomichevella najafi n. sp.}

(Figures $5 \mathrm{~A}_{1-6}, \mathrm{~B}_{1-2}$ )

1994 Fomichevella uralica (Dobrolyubova, 1936), Flügel, p. 607 , pl. 3 , figs. 1,2 .

Etymology. This species is named in honor of Dr. Mehdi Nadjafi, who encouraged the first author to study this fauna. Holotype. Specimen 90 BZ 5-13.

Type locality. East central Iran, Zaladu Section.

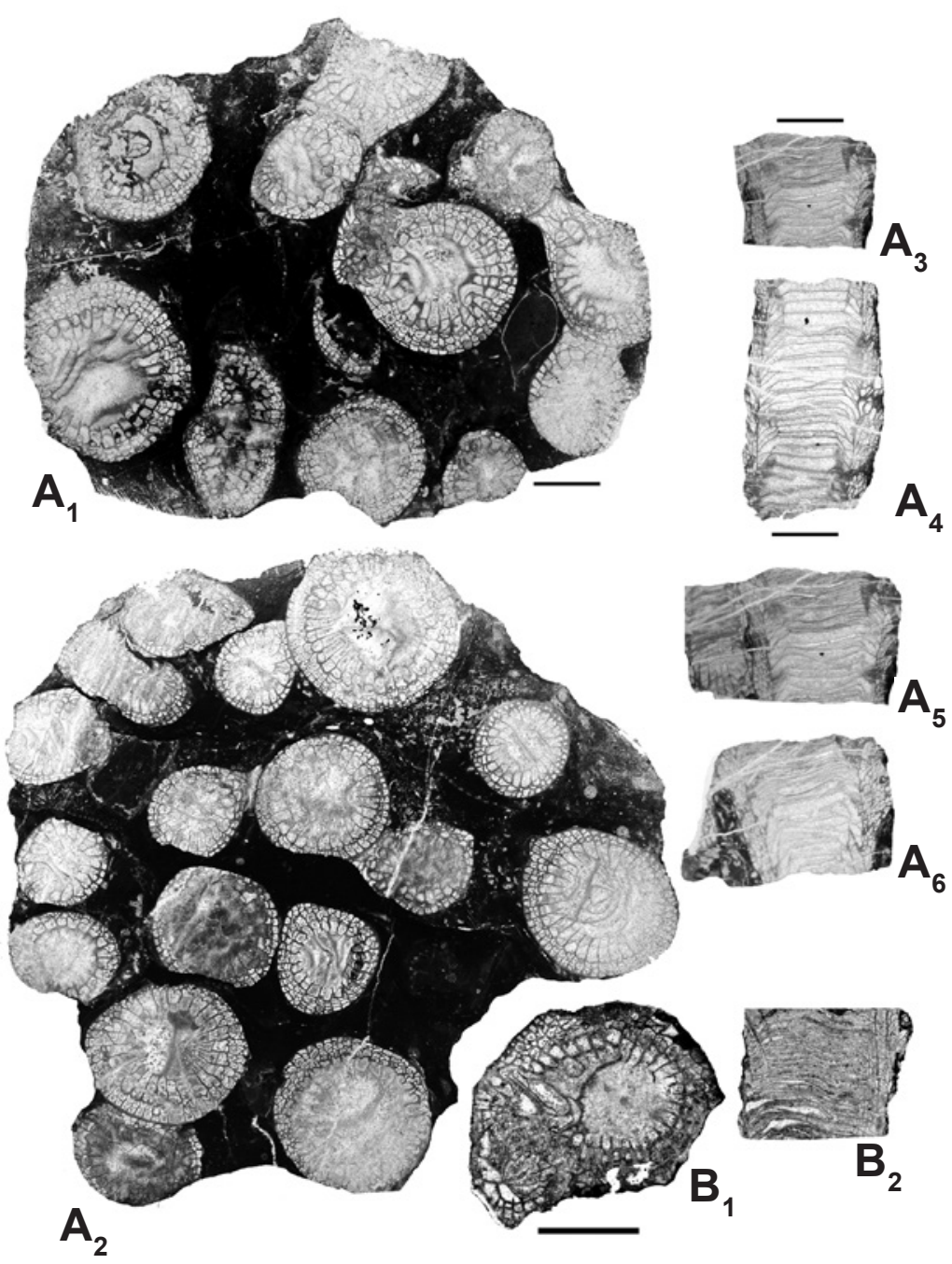

Figure 5. A-B, Fomichevella najafi n. sp. from the Zaladu Section: specimen 90BZ 5-13 (holotype), $\mathbf{A}_{1-2}$, successive transverse sections; $\mathbf{A}_{3-6}$, longitudinal sections; $\mathbf{B}$, specimen $90 \mathrm{BZ} 42, \mathbf{B}_{1}$, transverse sections, $\mathbf{B}_{2}$, longitudinal sections through specimen. Scale bars $=5 \mathrm{~mm}$. 
Type horizon. Early-middle Bashkirian, Sardar Formation. Material. Five colonies including the holotype (52 corallites in 15 transverse serial sections, 13 longitudinal sections, 90 BZ 5-13, Sdo8, BZ 16, BZ 53, BZ 42). Specimens 90 BZ 5-13, BZ 42, BZ 16 and, BZ 53 were collected in the Zaladu Section, Sdo 8 comes from the Shishtu Section, and the Tangal-e-zireh Section.

Occurrence. Early-middle Bashkirian, East central Iran, Ozbak-kuh Mountains.

Diagnosis. Fomichevella with n:d values 26-27:13-14 mm, 30-34:15 mm, 32-35:15.5-16 mm; dissepimentarium composed of up to eight rows of dissepiments; minor septa very different in length; cardinal septum maybe shortened but commonly indistinct; short cardinal fossula not always well developed.

Description. Corallum is phaceloid. Corallites are subcylindrical, closely spaced, with lateral increase. In transverse section, the outer wall is about $0.1-0.2 \mathrm{~mm}$ thick. Corallite are $10-16 \mathrm{~mm}$ in diameter. $\mathrm{n}$ : $\mathrm{d}$ values (number of septa to corallite diameter value) of corallites 20-24:8-8.5 mm, 21:9.5 mm, 2023:10 mm, 21-26:11-11.5 mm, 26-27:13-13.5 mm, 26:14 mm, $30-34: 15 \mathrm{~mm}, 32-35: 15.5-16 \mathrm{~mm}$ (Figure 6). The major septa are commonly 2-5 $\mathrm{mm}$ in length, straight or slightly sinuous, thin in dissepimentarium and dilated in tabularium, except near the axis. The cardinal septum may be shortened (Figure $5 \mathrm{~A}_{1}$ ) but commonly indistinct or as long as its neighboring major septa (Figures $5 \mathrm{~A}_{1,2}$ ). The cardinal fossula is commonly indistinct. The minor septa are differentiated in length, 0.2 to $1.0 \mathrm{~mm}$ and about $1 / 3$ of the length of the major septa (Figures $5 \mathrm{~A}_{1,2}, \mathrm{~B}_{1}$ ) and commonly penetrating into tabularium. The dissepimentarium is 2-4 mm wide and is composed of 1-8 rows of small, globose dissepiments at the periphery and elongated ones near the tabularium boundary, with inner walls of the innermost row thickened by sclerenchyma (Figures 5A-B). The tabularium is $7-11 \mathrm{~mm}$ wide, tabulae are complete and incomplete, mostly trapezoid, some slightly convex or sagging axially, with 1-3 long axial tabellae, attached to a given tabula; peripheral tabellae are rare, short, elevated less distinctly than peripheral parts of tabulae. There are about 12-17 tabulae per centimeter (Figures $5 \mathrm{~A}_{3-5}, \mathrm{~B}_{2}$ ).

Remarks. This species differs from the type species, Fomichevella hoeli Holtedahl, 1913 from the Upper

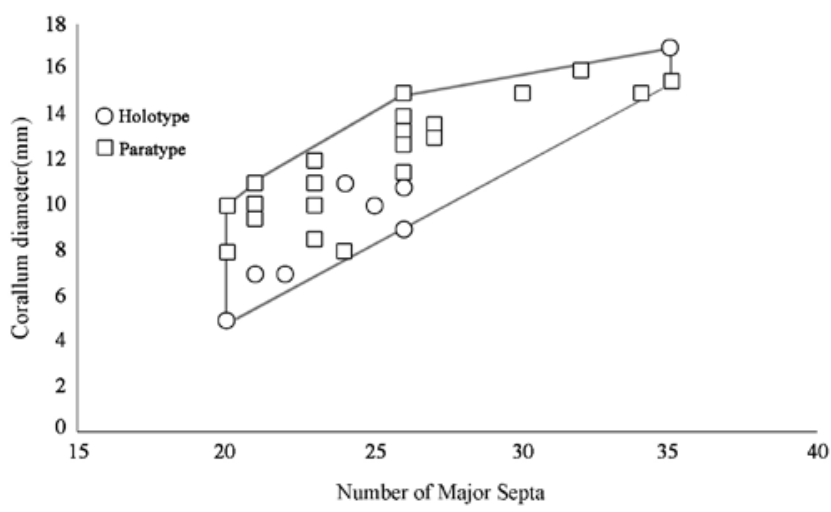

Figure 6. Scatter diagram showing the number of septa plotted against corallum diameter for Fomichevella najafi n. sp.
Carboniferous of west of Green Harbour, Vestspitsbergen, by smaller diameter and more septa or Iranian species in similar diameters has higher number of septa. $\mathrm{n}: \mathrm{d}$ values of Vestspitsbergen species is 24-31:16-20 mm, whereas Fomichevella najafi $\mathrm{n}$. sp. n:d has values of 26-27:13-14 $\mathrm{mm}, 30-34: 15 \mathrm{~mm}, 32-35: 15.5-16 \mathrm{~mm}$. The cardinal septum in the type species is slightly shortened but in the Iranian species is commonly indistinct. Tabulae of $F$. najafi n. sp. are complete and incomplete, mostly trapezoid, with 1-3 axial tabellae; peripheral tabellae are rare; but tabularium in the type species, F. hoeli is wide, with complete tabulae usually flat, less commonly slightly convex or concave. F. najafi n. sp. differs from the Ural species F. uralica (Dobrolyubova, 1936) by smaller diameter and less septa. Flügel (1994) reported F. uralica from the Bashkirian of the Ozbak-Kuh Mountains, but he did not notice to different $\mathrm{n}$ :d values of two species, so that Flügel's species n: d values of corallites 23-27:11-17 $\mathrm{mm}$, and in maximum in the mature corallites it has $30-31$ septa. But F. uralica has n:d values of 41: 24-33mm, 38: 23-30 $\mathrm{mm}, 36: 12-20 \mathrm{~mm}, 26: 15-18 \mathrm{~mm}$. The revision of topotypes of corals attributed to F. uralica by Flügel (1994) allow the re-attribution of this material to the new species $F$. najafin. sp.

The new species is similar in size to Fomichevella longiseptata Zhu \& Zhao, 1992 but has shorter septa. Moreover, F. longiseptata has major septa thick in tabularium and thin in dissepimentarium (particularly in the cardinal quadrants), whereas the thickness of the septa is constant in F. najafi n. sp. F. sotoi Rodríguez, 1984 from the Bashkirian of the Cantabrian Mountains has a similar diameter but have more septa and more regular dissepiments. Fomichevella najafi n. sp. is different from F. smithi Fontaine, Ibrahim \& Vachard, 2003 in diameter of corallites; Malaysian species has more septa (with $\mathrm{n}$ : $\mathrm{d}$ values 24-36:10-13 mm), in similar diameters in comparison with $F$. najafi n. sp. (with $\mathrm{n}$ : $\mathrm{d}$ values 20-27:10-13 mm), but Iranian species is longer than in size of corallites at maturity stage up to $27-35$ septa in $13-16 \mathrm{~mm}$; F. smithi have typical thick septa (Fontaine et al., 2003). Moreover, the minor septa of $F$. smithi are also longer (up to $3 / 4$ of the length of major septa whereas in F. najafi $n$. sp., they are about $1 / 3$ of the length of the major septa). The cardinal fossula of $F$. najafi n. sp. is commonly present but it is not well marked in F. smithi, moreover the Iranian species has more tabulae per centimeter.

\section{Heintzella Fedorowski, 1967}

Type species. Heintzella multiseptata Fedorowski, 1967, lower Permian, Treskelodden, Vestspitsbergen.

Diagnosis. Fasciculate Kleopatrinidae with axial structure interrupted, irregular, commonly lacking median lamella, open cardinal fossula generally present; cardinal septum variably shortened, lonsdaleoid dissepiments rarely present; microstructure finely trabecular (Fedorowski et al., 2007).

Heintzella fluegeli $\mathrm{n}$. sp.

(Figures $7 \mathrm{~A}_{1-12}$ ) 
Etymology. This species is named in honor of Dr. Helmut W. Flügel, who has contributed significantly to the study of Paleozoic corals of Iran.

Holotype. Specimen 90 BZ 5-14.

Type locality. East central Iran, Zaladu Section.

Type horizon. Middle Bashkirian, Sardar Formation.

Material. Four colonies including the holotype (17 Transverse sections, 3 longitudinal sections, 90 BZ 5-14, Sah 23, Sah 35, Sdo 27). Specimens 90 BZ 5-14, Sah 23, Sah 35 were collected in the Zaladu Section, Sdo 27 comes from the Tangal-e-zireh Section.

Occurrence. Middle Bashkirian, East central Iran, Ozbak kuh Mountains.

Diagnosis. Heinzella with n:d values of corallites 27-30:13 $\mathrm{mm}, 31: 16 \mathrm{~mm}$. Septa thin in dissepimentarium, taper axially. 3-6 rows of herringbone, pseudoherringbone dissepiments, regular dissepiments and few lonsdaleoid dissepiments interrupting minor septa.

Description. Corallum is phaceloid. Corallite walls are approximately $0.1 \mathrm{~mm}$ thick. Corallites are cylindrical, 12-16 $\mathrm{mm}$ in diameter. There are 26-31 septa of each order in mature corallites. $\mathrm{n}: \mathrm{d}$ values of corallites 27: 12-14 mm, 27-30:13 $\mathrm{mm}, 31: 16 \mathrm{~mm}$ (Figure 8). Septa are straight to sinuous. The major septa are generally $3-4.5 \mathrm{~mm}$-long $(\sim 1 / 2$ corallite radius), except for cardinal septum, which is commonly shortened; 1-1.5 mm in length (Figures $7 \mathrm{~A}_{3,6,8-11}$ ) or may be as long as neighboring major septa. The major septa are thin in the dissepimentarium and dilated in the tabularium, tapering axially. The minor septa have different length; they are $0.5-2 \mathrm{~mm}$ long, generally confined to dissepimentarium (Figure $7 \mathrm{~A}_{3}$ ), some may penetrate tabularium (Figure $7 \mathrm{~A}_{8}$ ), some of them interrupted by small lonsdaleoid dissepiments (Figure $7 \mathrm{~A}_{6,8-10}$ ). The cardinal fossula is distinct (Figures $7 \mathrm{~A}_{3,4,69,10}$ ) but not always well developed (Figure $7 \mathrm{~A}_{1,5,7}$ ). The axial structure is very simple, composed of a weak median plate sometimes attached to the axial ends of one major septa. There are occasional axial tabellae. The dissepimentarium is 2.5-4 mm wide with 3-6 rows of mostly herringbone and pseudo-herringbone dissepiments (Figures $7 \mathrm{~A}_{4,6}$ ). Regular interseptal dissepiments are common (Figures $7 \mathrm{~A}_{1,4,11}$ ). There are few lonsdaleoid dissepiments (Figures $7 \mathrm{~A}_{6,9-11}$ ). Tabulae are complete and incomplete, locally steeply elevated toward median lamella (Figure $7 \mathrm{~A}_{12}$ ), mostly trapezoid, some slightly convex or sagging, long axial tabellae are attached to a simple median plate. They are short, elevated less distinctly than peripheral parts of tabulae. There are about 12 tabulae per $\mathrm{cm}$ (Figure $7 \mathrm{~A}_{12}$ ).

Remarks. Heintzella fluegeli n. sp. is distinguished from the type species, $H$. multiseptata Fedorowski, 1967 from the Lower Permian of Vestspitsbergen, by its smaller diameter

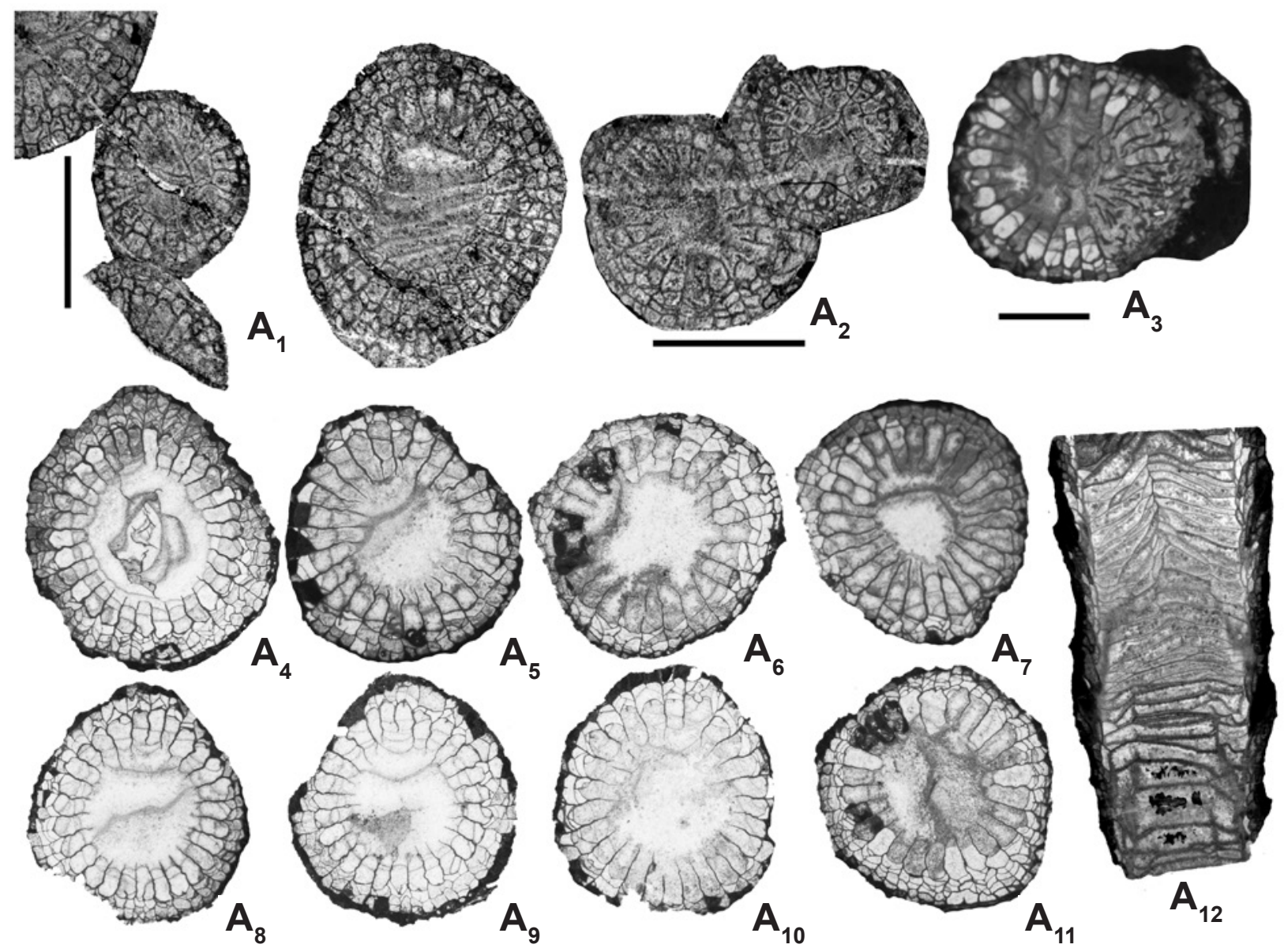

Figure 7. A, Heintzella fluegeli n. sp. from Zaladu Section: A, specimen 90BZ5-14, holotype, $\mathbf{A}_{1-11}$, successive transverse sections, $\mathbf{A}_{12}$, longitudinal section. Scale bars $=5 \mathrm{~mm}$. 
and fewer septa. Vestspitsbergen species with $\mathrm{n}: \mathrm{d}$ values of $30-38: 18-22 \mathrm{~mm}$ is different from the Iranian species with values of 27-31:12-16mm. H. multiseptata has longer major septa than the Iranian specimens ( $3 / 4$ radius in Vestspitsbergen coral, whereas about $1 / 2$ corallite radius in the Iranian species). The minor septa of $H$. multiseptata are longer than minor septa of Iranian species. Minor septa reach to $1 / 3$ of corallite radius and are more penetrated into tabularium in $H$. multiseptata but they are different in length, less than $1 / 2$ to $1 / 3$ length of the major septa and generally confined to dissepimentarium in $H$. fluegeli $\mathrm{n}$. sp. Dissepimentarium is narrow in $H$. fluegeli n. sp. (less than $1 / 4$ of corallite radius, whereas this value is $1 / 3$ in $H$. multiseptata). Heintzella fluegeli n. sp. has weak, vertically interrupted median lamellae, simpler axial structure and better developed dissepiments than Heintzella borealis Fedorowski, Bamber \& Stevens, 2007) from early (?) Sakmarian of Spitsbergen and Canada. $H$. fluegeli n. sp. has 3-6 rows of herringbone, pseudoherringbone dissepiments, concentric dissepiments, and fewer lonsdaleoid dissepiments, whereas $H$. borealis has 2-3 rows of irregular interseptal dissepiments. Moreover, $H$. borealis differs from the new species by longer minor septa and weaker sinuosity characteristic of the major septa. The minor septa of H. borealis are mostly penetrated into tabulae but in Heintzella fluegeli n. sp., they are much different in length and generally confined to dissepimentarium. Dissepimentarium width in H. fluegeli $\mathrm{n}$. sp. is less than of $1 / 4$ radius, whereas it is measured $1 / 3$ in $H$. borealis). Heintzella radiata (Fedorowski, 1965) has a thicker axial plate. H. densiseptata (Fedorowski, 1964) has a denser axial structure.

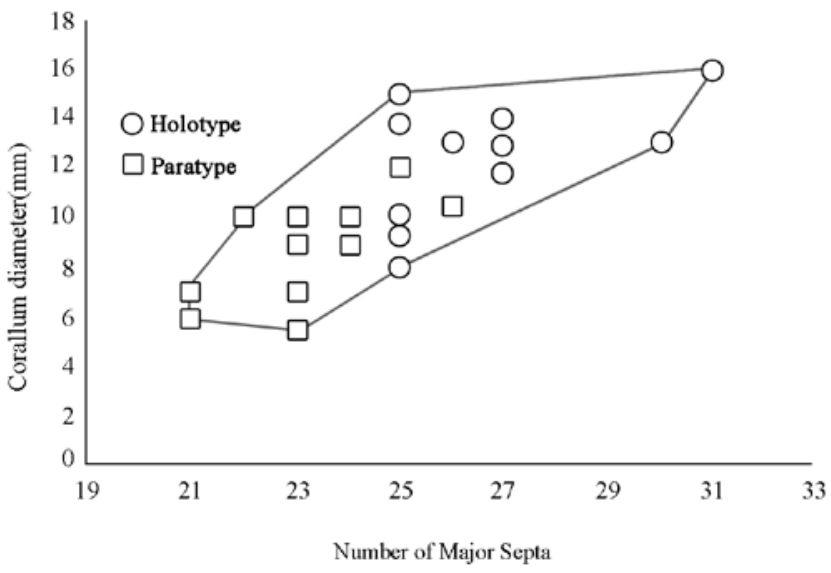

Figure 8. Scatter diagram showing the number of septa plotted against corallum diameter for Heintzella fluegeli $\mathrm{n}$. sp.

\section{Paraheritschioides Sando, 1985}

Type species. Paraheritschioides grandis Sando, 1985, Upper Pennsylvanian Oquirrh Formation of the Western Interior Region (Idaho, USA).

Diagnosis. Fasciculate Kleopatrinidae with axial structure that may disappeared over short intervals of growth; discontinuous axial column within axial structure variably developed, complex in some species; median lamella closely connected to counter septum; cardinal septum variable, not shortened in some corallites; dissepiments locally lonsdaleoid; tabularium indistinctly biform (Fedorowski et al., 2007; Fedorowski \& Stevens, 2014).

Paraheritschioides antoni Flügel, 1994

1994 Paraheritschiodes antoni Flügel, p. 604, pl. 3, fig. 5,6; pl. 2, figs. 2-4.

Emended diagnosis. Paraheritschioides with $10-20 \mathrm{~mm}$ in diameter and 23-35; major septa slightly withdrawn from axial structure consisting of a variable median plate and rare, short septal lamellae; major septa thin in dissepimentarium, dilated in tabularium; cardinal septum varies in length, equal to adjacent major septa in some corallites; cardinal fossula indistinct; minor septa half as long as major septa, locally entering tabularium; dissepiments herringbone, pseudoherringbone, concentric and lonsdaleoid.

\section{Paraheritschioides antoni antoni Flügel, 1994}

(Figures 9 $\mathrm{A}_{1-5}, \mathrm{~B}_{1-2,} \mathrm{C}_{1-7}$ )

1994 Paraheritschiodes antoni antoni Flügel, p. 604, pl. 3, figs. 5, 6 .

Material. Fragments of three colonies (Vch 14, Vch 19, Vch 150). (25 transverse sections, five longitudinal sections). Colonies fragments of Vch 14, Vch 19 and Vch 150 were collected in the Cheshmeh-Shir Section.

Age and occurrence. Middle Bashkirian, East central Iran, Ozbak kuh Mountains.

Emended diagnosis. Subspecies characterized with n:d values 30:10-13 mm, 31:14mm, 32-35:15-20 mm. Dissepimentarium more complex with small lonsdaleoid dissepiments; cardinal septum shortened.

Description. Corallites are sub-cylindrical. There are 30-35 septa of each order at a diameter of 14-19 mm (Figures 9A $\left.\mathrm{B}_{1,2}, \mathrm{C}_{1-7}\right)$ in mature corallites. $\mathrm{n}$ : $\mathrm{d}$ values $21: 6 \mathrm{~mm}, 25-27: 8-$ $10 \mathrm{~mm}, 30: 10-13 \mathrm{~mm}, 31: 14 \mathrm{~mm}, 32-35: 15-20 \mathrm{~mm}$ (Figure $10)$. The major septa are about $2 / 3$ of the corallite radius, commonly 5-7 $\mathrm{mm}$ long and 0.2-0.3 mm-thick, generally withdrawn from the axial structure, straight to slightly sinuous, dilated in tabularium and tapered axially. The cardinal septum is shortened (Figures $9 \mathrm{~A}_{1-5}, \mathrm{~B}_{1,2}$ ) or may be as long as neighboring major septa (Figures $9 \mathrm{C}_{1,2,6}$ ). The counter septum is commonly elongated (Figures $9 \mathrm{~A}_{1,2}$ ). The minor septa are half as long as the major septa (1.5-2.5 mm-long) and restricted to the peripheral part of the dissepimentarium.

The axial structure is variable in width in mature corallites. They are connected to some or most major septa (Figures $9 \mathrm{~A}_{1,2}, \mathrm{C}_{1-7}$ ), consisting of thin median lamella, more septal lamellae and/or inner margins of major septa, and several very steeply inclined axial tabellae (Figures $9 \mathrm{C}_{1-7}$ ) to form distinct axial column. Axial structure in general trend from weakest in early ontogeny with few lamellae, to fairly 


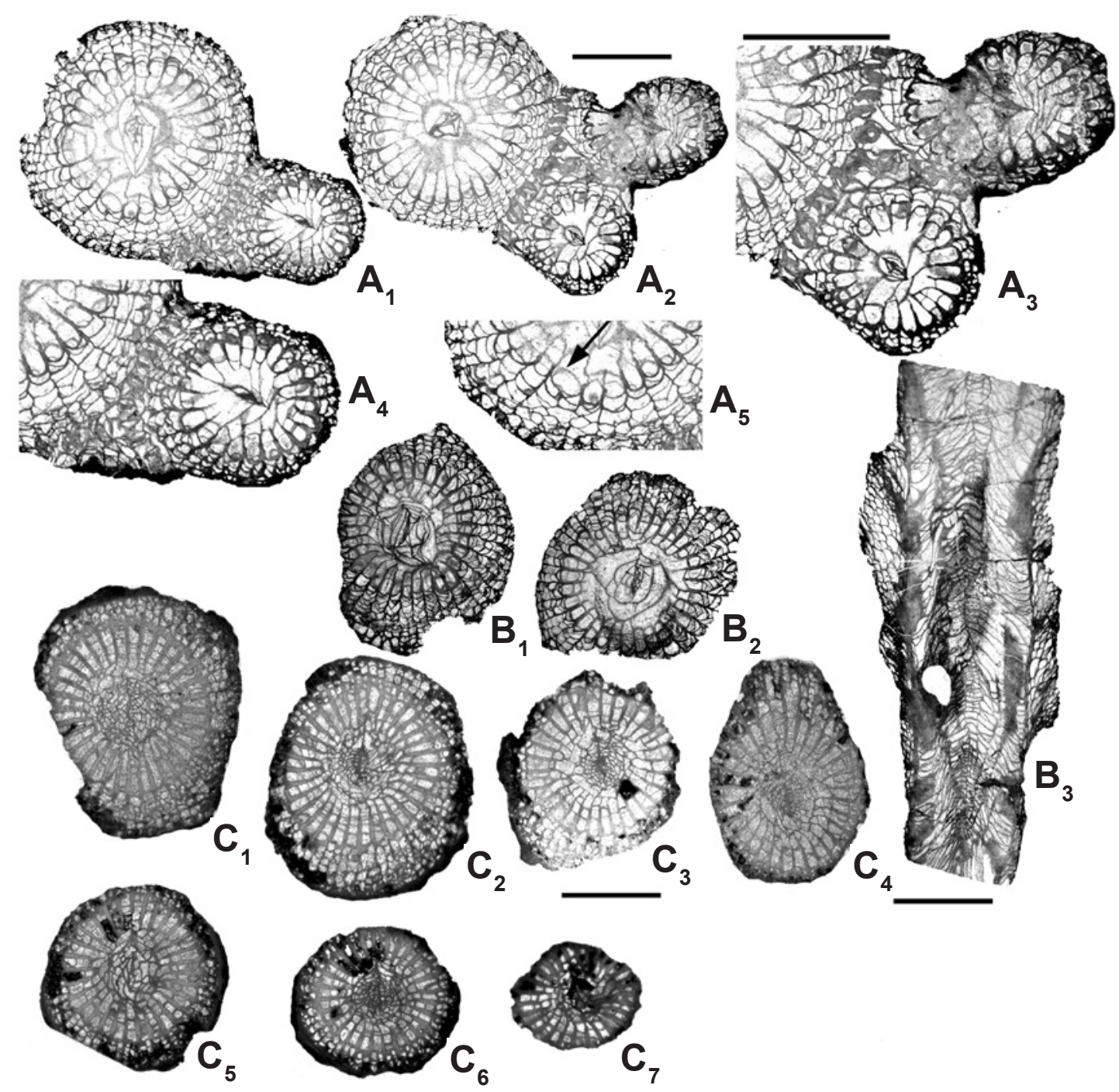

Figure 9. Paraheritschiodes antoni antoni (Flügel, 1994) from Cheshmeh-Shir Section: A, specimen Vch19, $\mathbf{A}_{1-2}$, successive transverse sections, $\mathbf{A}_{3}$, enlarged from $A_{2}$, young corallite with simple axial structure connected to counter septum, $\mathbf{A}_{4}$, enlarged from $A_{1}$, young corallite with simple axial structure connected to counter septum, $\mathbf{A}_{5}$, enlarged from $\mathbf{A}_{1}$ to document biform morphology; $\mathbf{B}$, specimen Vch14, $\mathbf{B}_{1-2}$, transverse sections, $\mathbf{B}_{3}$, longitudinal section; $\mathbf{C}$, specimen Vch150, $\mathbf{C}_{1-7}$, successive transverse sections. Scale bars $=5 \mathrm{~mm}$.

complex at maturity (Figures $9 \mathrm{~A}_{1,2}, \mathrm{C}_{1-7}$ ). Several exceptions to general trend occur: axial structure may be comparatively complex in early ontogeny (Figure $9 \mathrm{C}_{7}$ ) or weak at maturity (Figures 9 $\mathrm{A}_{1,2}$ ); median lamella elongated, thin curved and commonly attached to counter septum (Figures $9 \mathrm{~A}_{1,2}$ ), thus indicating its derivation from that septum; in weak axial structure axial tabellae are strongly reduced in number. The dissepimentarium is 4-8 mm-wide and composed of 5-7 rows of mostly herringbone, pseudo-herringbone, and few lonsdaleoid dissepiments (Figures 9 $\mathrm{A}_{1,2}$ ). The tabularium is 5-12 mm-wide, with biform morphology (Figures $9 \mathrm{~A}_{1-5}$ ). It consists of mostly complete tabulae and several very steeply inclined axial tabellae (Figures $9 \mathrm{C}_{1-7}$ ) to form distinct axial column. There are 14-16 tabulae per centimeter (Figures 9B $\mathrm{B}_{12}$ ).

Remarks. The present specimens have lonsdaleoid dissepiments, the feature that is not present in the holotype of Paraheritschioides antoni antoni. Heritschioides vepres
Flügel, 1994 from the Bashkirian of central Iran, has an axial plate elongated towards the cardinal septum, more extra septal lamellae in the axial structure, which is isolated from the tabularium by vertically arranged lateral tabellae. Unlike $H$. vepres, $P$. antoni antoni possesses a continuous to discontinuous axial structure with a discontinuous axial column and its median lamella is connected to counter septum. Protodurhamina strelzovkensis Kozyreva, 1978 unlike Paraheritschioides do not clearly show the shortened cardinal septum or the linked axial tabellae. In addition, P. antoni antoni differs from latter Russian species by the median lamella of axial structure connected to counter septum in young corallite and lonsdaleoid dissepiments. Fedorowski (2004) emended the diagnosis of Corwenia and stated that the median lamella of Corwenia stronger connected with cardinal septum and there are open cardinal fossula. P. antoni antoni differs from Heintzella stuckenbergi (Dobrolyubova, 1936), from the Ural; Iranian species with similar diameters has higher number of 
septa; moreover has a stronger median lamella and complex axial structure and lonsdaleoid dissepiments.

Paraheritschioides antoni antoni differs from P. jagoensis (Armstrong, 1972) from the early Atokan (Bashkirian) of Alaska and NW California by more septa and a simpler axial structure. $P$. antoni antoni has $\mathrm{n}: \mathrm{d}$ values $30: 10-13 \mathrm{~mm}, 31: 14 \mathrm{~mm}, 32-$ $35: 15-20 \mathrm{~mm}$ but these values are measured $29-32: 16-18 \mathrm{~mm}$ in P. jagoensis. Paraheritschioides compositus Fedorowski \& Stevens, 2014 from the early Atokan (Bashkirian) and P. katvalae Fedorowski \& Stevens, 2014 from the Moscovian of Alaska and NW California differs from $P$. antoni antoni by a smaller diameter, less septa, major septa approaching to the axial structure and a narrow dissepimentarium.

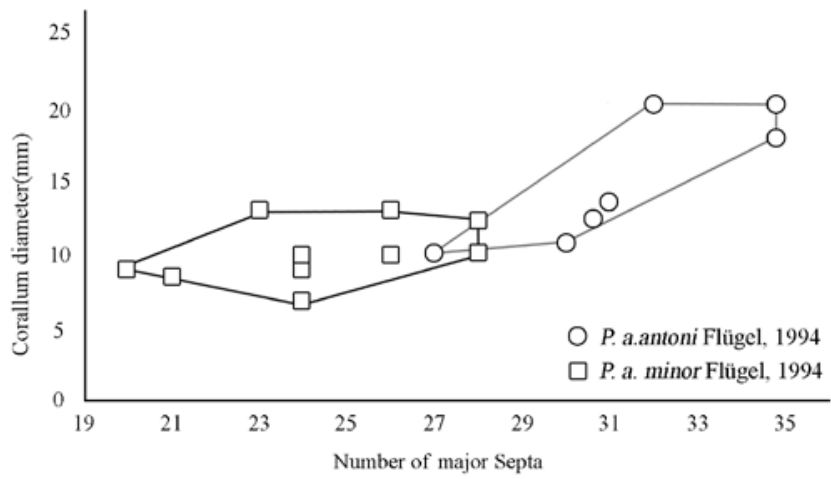

Figure 10. Scatter diagram showing the number of septa plotted against corallum diameter for Paraheritschiodes antoni antoni (Flügel, 1994) and $P$. antoni minor (Flügel, 1994).

Paraheritschioides antoni minor Flügel, 1994

(Figures 11 $\mathrm{A}_{1-6}, \mathrm{~B}_{1-3}, \mathrm{C}_{1-4}, \mathrm{D}_{1-5}$ )

1994 Paraheritschioides antoni minor Flügel, p. 605, pl. 2, figs. 2-4.

Material. Fragments of six colonies (Sdo 7, Sdo 22, Sdo 24, Sdo 121, Sdo 123, Sdo 130, Sz 5, Sz 6, Sz 8 ) (17 transverse sections and 8 longitudinal sections). Colony fragments Sdo 7, Sdo 22, Sdo 24, Sdo 121, Sdo 123 and Sdo 130 were collected in the E-Shishtu Village, in the Tangal-e-zireh Section. Colonies of Sz 5, Sz 6 and Sz 8 collected in the Zaladu Section.

Age and occurrence. Middle Bashkirian, East central Iran, Ozbak kuh Mountains.

Emended diagnosis. Subspecies characterized with n:d values $23-28: 10-14 \mathrm{~mm}$. cardinal septums slightly shortened, counter septum elongated.

Description. The corallites are sub-cylindrical, $6.5-14 \mathrm{~mm}$ in diameter. There are 19-28 septa of each order (Figure 11), $\mathrm{n}: \mathrm{d}$ values 19:6.5 mm, 22-24:7 mm, 21: 8.5-9.5 mm, 20-24:9 mm, 23-26:10 mm, 28:10.5 mm, 23-28:11-13 mm (Figure 10). The major septa are commonly $2-4 \mathrm{~mm}$-long and 0.25 mm-thick. They are straight, more than $2 / 3$ of the corallite radius in length, mostly withdrawn from the axial structure. The cardinal septum is slightly shortened and 1.5-3.5 mm-long (Figures $11 \mathrm{~A}_{1,2,4,5}, \mathrm{D}_{1-4}$ ). The axial ends of some major septa are connected to the margin of the axial structure. The minor septa are 1-2 mm long, and extend into the tabularium. The axial structure consists of a thin elongated median lamella 2-4 mm long (Figures $11 \mathrm{~A}_{1,2,4}, \mathrm{C}_{1-3}, \mathrm{D}_{1-4}$ ), commonly attached to counter septum (Figures $11 \mathrm{~A}_{1,2,4,5,6}, \mathrm{C}_{3}, \mathrm{D}_{1-4}$ ) and a few septal lamellae (Figures $10 \mathrm{~A}_{4,5}, \mathrm{~B}_{3}, \mathrm{C}_{1,2}, \mathrm{D}_{1-4}$ ). Morphology of the axial structure varies at the mature growth stage from comparatively simple to complex with several septal lamellae incorporated (Figures $11 \mathrm{~A}_{5}, \mathrm{~B}_{1,2}$ ). The dissepimentarium is 2-4 mm wide, consists of 1-7 rows of concentric dissepiments. The tabularium is $5-8.5 \mathrm{~mm}$-wide, composed of generally concave, complete tabulae and several steeply inclined axial tabellae (Figures $11 \mathrm{C}_{4}, \mathrm{D}_{5}$ ) to form interrupted axial column. There are 16 tabulae per centimeter (Figures $11 \mathrm{C}_{4}, \mathrm{D}_{5}$ ).

Remarks. This subspecies does not appear to be a durhaminid, as suggested by Fedorowski et al. (2007, p. 96), because the smallest specimen shows major septa, except for the counter septum, withdrawn from the axial region, the cardinal septum is shortened, and the axial structure is continuous, however this species is assigned to the Kleopatrinidae.

Paraheritschioides antoni minor differs from P. jagoensis (Armstrong, 1972) from the early Atokan (Bashkirian) of Alaska and NW California by a smaller diameter, less septa (P. antoni minor with $\mathrm{n}: \mathrm{d}$ values $23-26: 10 \mathrm{~mm}, 28: 10.5 \mathrm{~mm}$, 23-28:11-13 mm but $P$. jagoensis with n:d values 29-32:16$18 \mathrm{~mm}$ ); simpler axial structure and narrow dissepimentarium. Paraheritschioides compositus Fedorowski \& Stevens, 2014 from the early Atokan (Bashkirian) of Alaska and NW California is distinguished from $P$. antoni minor by more developed axial structure, narrow dissepimentarium and major septa approaching the axial structure; $\mathrm{n}: \mathrm{d}$ values of $P$. compositus are $23: 8 \mathrm{~mm}$ to $25: 9.5 \mathrm{~mm}$; but $P$. antoni minor has a larger diameter and more septa with values of 23-26:10 $\mathrm{mm}, 28: 10.5 \mathrm{~mm}, 23-28: 11-13 \mathrm{~mm}$. Paraheritschioides katvalae Fedorowski \& Stevens, 2014 from the Moscovian of Alaska and NW California differs from P. antoni minor by a smaller diameter, less septa number (most common n:d value 20:7.0mm.), more developed axial structure and narrow dissepimentarium.

In comparison with the type species of the genus, Paraheritschioides grandis (Sando, 1985) from the upper Pennsylvanian (Missourian or Virgilian) of Idaho, P. antoni minor has a wider range of dimensions, shorter major septa and more rows of dissepiments. However, $P$. grandis has some large lonsdaleoid dissepiments whereas $P$. antoni minor has none.

\section{Paraheritschioides gracilis Flügel, 1994} (Figures $12 \mathrm{~A}_{1-9}, \mathrm{~B}, \mathrm{C}_{1-5}$ )

1994 Paraheritschiodes gracilis Flügel, p. 605, pl. 3, figs. 8-10.

Material. Four colonies (C4, BZ 87, Sdo6, Sdo 21). (five transverse sections, two longitudinal section). Colonies specimens BZ 87 and C4 collected in the Zaladu Section, specimens Sdo6, and Sdo 21 were collected in the the Tangale-zireh Section. 
Occurrence. Middle Bashkirian, East central Iran, Ozbak kuh Mountains.

Emended diagnosis. Paraheritschioides with $\mathrm{n}$ :d values 26:10 $\mathrm{mm}$ to $20: 7.5-8 \mathrm{~mm}$; major septa mainly withdrawn from corallite axis; most minor septa intersect narrow dissepimentarium; axial structure consists of thin median lamella alone, with a few septal lamellae in some corallites. Description. The corallites are sub-cylindrical with lateral increase and thin walls. They are $6-10 \mathrm{~mm}$ in diameter and have19-26 septa of each order; $n: d$ values of mature corallites 19:6 mm, 20:7.5-8, 21:8 mm, 26:10 mm (Figure 13). The major septa are commonly $1-4$ mm-long $(1 / 2-2 / 3$ of the corallite radius) and less than $0.1 \mathrm{~mm}$-thick, straight to slightly sinuous, tapering axially. The cardinal septum is shortened; the counter septum is occasionally elongated (Figures $12 \mathrm{~A}_{1,4,5}$, $\mathrm{B}, \mathrm{C}_{2}$ ). The minor septa vary in length between corallites and at different growth levels of individual corallites, they mostly $0.5-1.5 \mathrm{~mm}$ long, and $1 / 2-1 / 3$ of the major septa, inner margins of longest minor septa thin, penetrate tabularium (Figures $12 \mathrm{~A}_{7,8}, \mathrm{~B}, \mathrm{C}_{3,4}$ ). The axial structure is discontinuous and simple. It consists of the thin median lamella accompanied by a few, short septal lamellae, the inner margins of major septa in some corallies, and some very steeply inclined axial tabellae (Figures 12 $\mathrm{A}_{2,3,4,5}, \mathrm{~B}, \mathrm{C}_{1,5}$ ). The median lamella may
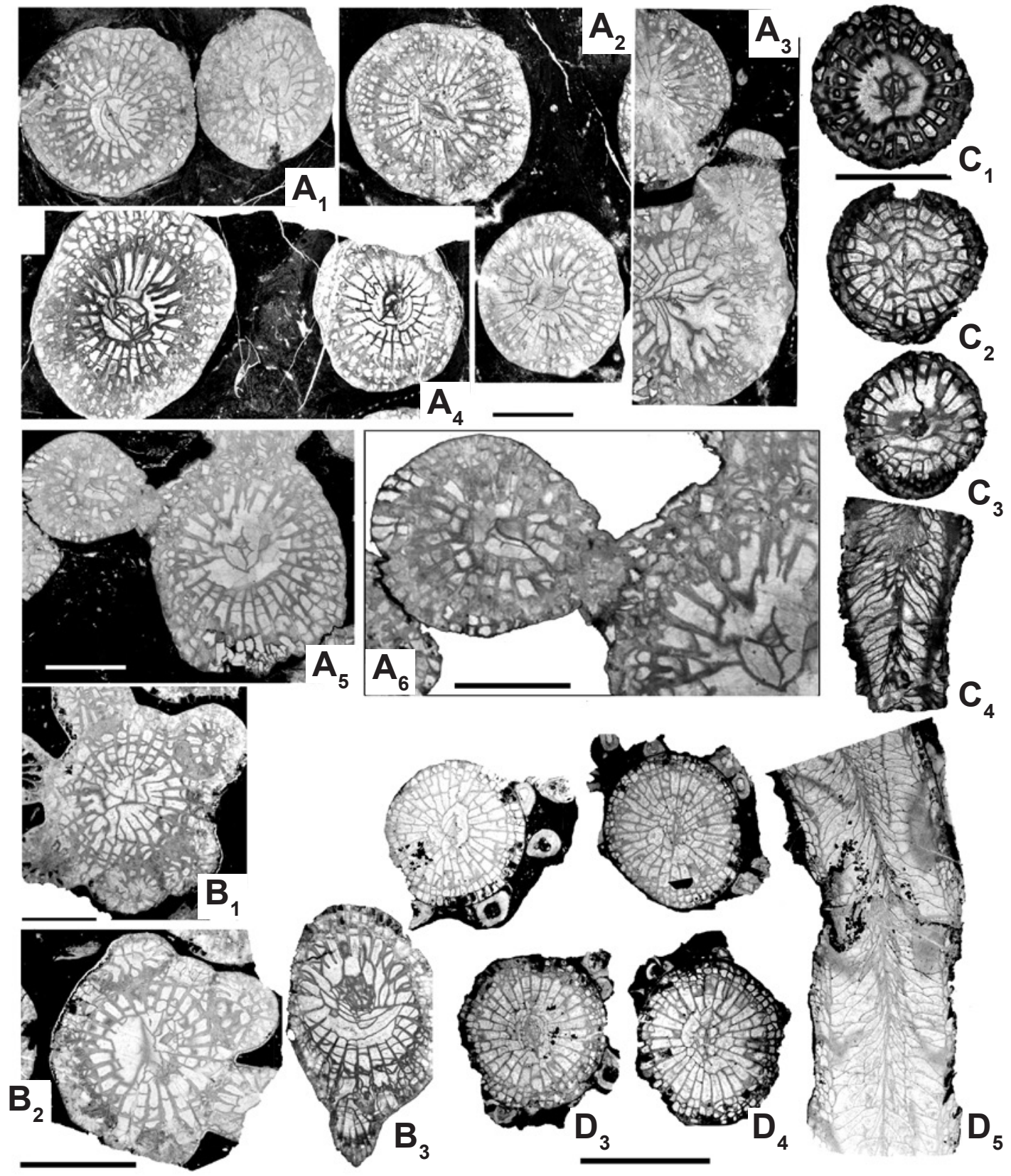

\section{.}


be absent from a weak axial structure (Figures 12 $\mathrm{A}_{1}, \mathrm{~B}, \mathrm{C}_{2-4}$ ); when present, median lamella elongated, thin, irregularly curved and commonly attached to counter septum (Figures $\left.12 \mathrm{~A}_{1,4-6}, \mathrm{~B}\right)$; in weak axial structure axial tabellae strongly reduced in number or absent. The dissepimentarium is narrow, 0.5-3.5 mm wide, which mostly composed of 2-3 rows of regular and concentric dissepiments. The tabularium is $1-5$ $\mathrm{mm}$ wide; it consists of mostly complete tabulae, gently elevated towards the axial structure and some steeply inclined axial tabellae (Figures $12 \mathrm{~A}_{23}, \mathrm{C}_{5}$ ). There are about 12 tabulae per centimeter (Figures $12 \mathrm{~A}_{2,3}, \mathrm{C}_{5}$ ).

Remarks. Paraheritschioides gracilis bears all the main characteristics of the genus, although none is fully developed. This species is readily distinguishable by this simple feature from another species of the genus. P. gracilis differs from the type species $P$. grandis (Sando, 1985) from the late Pennsylvanian (Missourian or Virgilian) of Idaho by a smaller diameter, a less complex axial structure with lesser tabellae
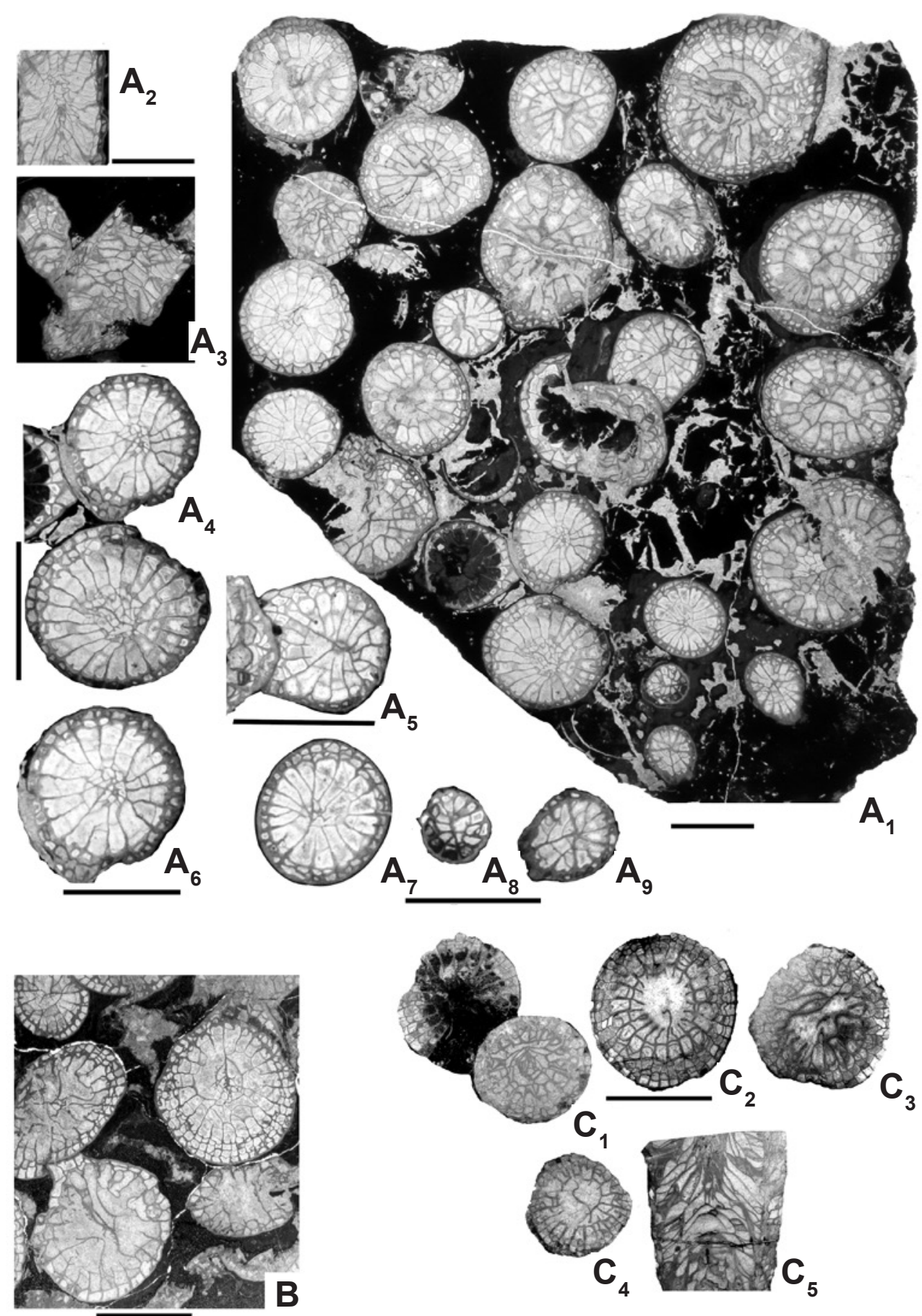

Figure 12. Paraheritschioides gracilis (Flügel, 1994): $\mathbf{A}$, specimen Sdo6, $\mathbf{A}_{1}$, transverse section, $\mathbf{A}_{2-3}$, longitudinal sections, $\mathbf{A}_{4-9}$, transverse sections, enlarged from $A_{1}$, corallites with simple axial structure connected to counter septum; $\mathbf{B}$, specimen $\mathbf{C} 4$, transverse section; $\mathbf{C}$, specimen Bz87, $C_{1-4}$, successive transverse sections, $C_{5}$, longitudinal section. Scale bars $=5 \mathrm{~mm}$. 


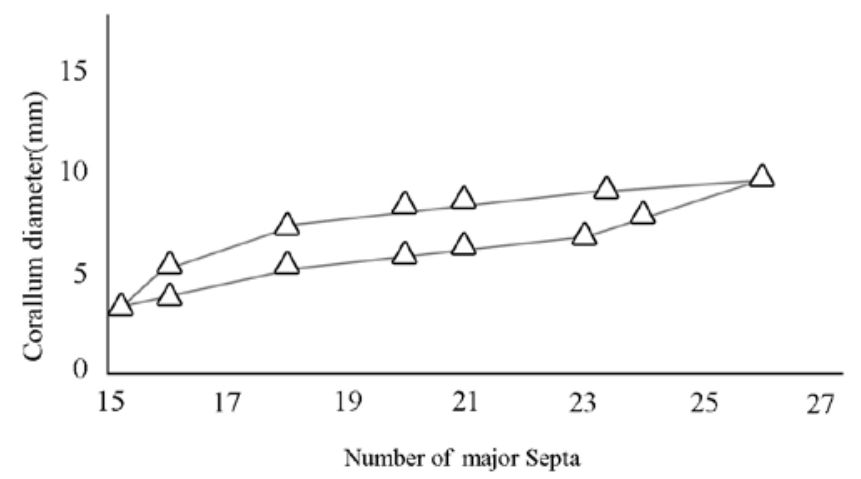

Figure 13. Scatter diagram showing the number of septa plotted against corallum diameter for Paraheritschiodes gracilis (Flügel, 1994).

and axial lamellae. Paraheritschioides sp. (Fedorowski et al., 2012) from the late? Bashkirian of the Sverdrup Basin with $\mathrm{n}: \mathrm{d}$ values of mature corallites 16:5.9 mm, 16:6.5 mm, 17:7.0 $\mathrm{mm}$. is smaller and has less septa than $P$. gracilis with $\mathrm{n}: \mathrm{d}$ values 20:7.5-8 mm, 26:10 mm. Paraheritschioides $\mathrm{sp}$. has a more complex axial structure, more tabellae and more axial lamellae (Fedorowski et al., 2012). P. compositus Fedorowski \& Stevens, 2014 from the early Atokan (Bashkirian) of Alaska and NW California is distinguished from $P$. gracilis by more developed axial structure with more septal lamellae and axial tabellae, longer major septa approaching to the axial structure. P. katvalae Fedorowski \& Stevens, 2014 from the Moscovian of Alaska and NW California differs from $P$. gracilis. Maximum corallite diameter of $P$. katvalae is $7.5 \mathrm{~mm}$. In this species $\mathrm{n}: \mathrm{d}$ values are $18: 6.5 \mathrm{~mm}, 19: 6.3 \mathrm{~mm}$, $20: 6.0,6.5,7.0,7.5 \mathrm{~mm}, 21: 6.0,7.0 \mathrm{~mm}$. with most common $\mathrm{n}: \mathrm{d}$ value of $20: 7.0 \mathrm{~mm}$, but the Iranian species has a larger diameter and more septa with values of 19:6 mm, 20:7.5-8, $21: 8 \mathrm{~mm}, 26: 10 \mathrm{~mm}$. P. katvalae has longer major septa, more developed axial structure with more tabellae and more axial lamellae and thickened median lamella.

\section{DISCUSSION}

There are few studies about the Late Carboniferous coral faunas in the Central and the other localities in Iran. Therefore, conducting a study to find out the similarities within these areas can be troublesome. In addition, the information on the Late Carboniferous coral faunas of the Ozbak-kuh Mountains in the East Central Iran is confined to a few works (e.g. Flügel, 1974, 1975, 1994). Nonetheless, the studies carried out by Flügel $(1974,1975,1994)$ provide little information on morphological variability of the region; hence, making a thorough comparison can be problematic. Moreover, there are still unanswered questions with regard to the coral faunas of the above-mentioned areas, especially the colonial forms which were taxonomically revised and summarized by Fedorowski et al. (2007, 2012, 2014a,b), and Fedorowski \& Stevens (2014).

Flügel (1994) reported the genus Paraheritschioides in the Ozbak-kuh Mountains and suggested that it belongs to Bashkirian age. His suggestion was based on the studies of brachiopods carried out by Stepanov (1971) and conodonts conducted by Weddige (1984). In addition, the findings of the studies on foraminiferal (Sohrabi, 2005; Leven et al., 2006) and conodonts data (Sohrabi, 2005) corroborate Flügel's suggestion. However, we found a new composition of corals in these studied areas that indicated the late Serpukhovian/ early Bashkirian foraminifers and conodonts (Sohrabi, 2005) and allowed a new approach to the genus Paraheritschioides by Badpa et al. (2011).

Fedorowski et al. (2007, p. 96) mentioned that "Generic affinities are difficult to determine for the Bashkirian species described by Flügel (1994, p. 604-606) and assigned to Paraheritschioides." They excluded these species from the genus "because they appear to have durhaminid or clisiophyllid morphology in their axial structures" (Fedorowski et al., 2007, p. 96). Unfortunately, we did not have access to the holotype and paratypes of Flügel's species; however, in this study, we collected many topotype materials from the type localities that had been studied by Flügel (1994). The Paraheritschioides that we found belong to the family Kleopatrinidae. The Paraheritschioides that we studied are similar in $\mathrm{n}: \mathrm{d}$ values to Flügel's species. In addition, because they have the median lamella derived from the counter septum in offsets they belong to the family Kleopatrinidae. Thus, contrary to Fedorowski et al. (2007) opinion, Flügel's and our samples have the main characters of genus Paraheritschioides.

The revision of topotypes of corals attributed to Fomichevella uralica by Flügel (1994) allowed the reattribution of this material to a new species called F. najafi n. sp. that differs from the Russian species by smaller diameter and less septa number. Flügel (1994) reported $F$. uralica from the Bashkirian of the Ozbak-Kuh Mountains, but he did not reported the $\mathrm{n}: \mathrm{d}$ values of two species.

\section{Palaeobiogeography}

The Ozbak-Kuh Mountains (in East Central Iran) were the north-west margin of Gondwana (Figure 14) and edged northward by a carbonate platform during the late Carboniferous. Contrary to the other parts of Iran in the Ozbakkuh Mnts. (In East Central Iran) marine conditions did not change considerably and the shallow water carbonate ramp of Visean continued to Moscovian.

Based on their species level, these fauna are local to Central Iran; therefore, there is no faunistic connection or relation between coral faunas of the Central Iran and the neighbouring blocks.

Based on their generic level, Fomichevella, Heintzella and Paraheritschioides are confined to the study areas and have not been reported from other parts of Iran. Fomichevella and Heintzella are present around cratonic margin of Laurasia, the Chinese microcontinent, and northernmost Gondwana and in North America during the Carboniferous (GarcíaBellido \& Rodríguez, 2005) (Figure 14). The presence of Paraheritschioides among the Central Iran coral composition is remarkably similar to the fauna reported from C.A.U realm (Fedorowski et al., 2007) such as the Arctic Canada, the northwestern margin of the Sverdrup Basin (Fedorowski et al., 


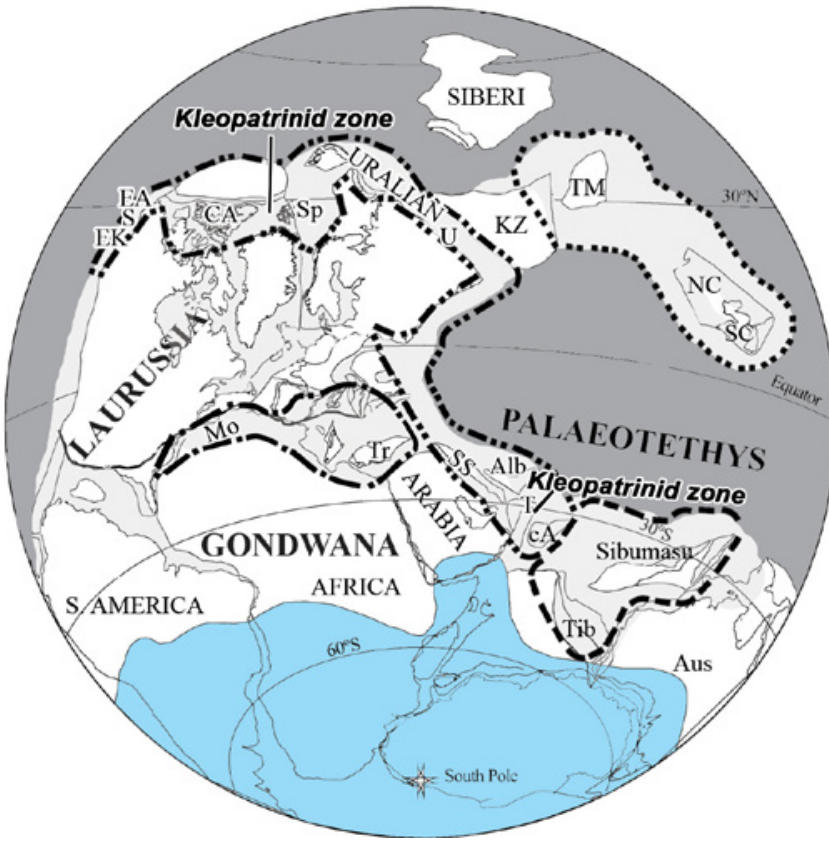

Figure 14. Distribution of Kleopatrinidae coral faunas in bioprovinces of the Late Carboniferous (320Ma). Abbreviations: KZ, Khazakhstan; U, Urals; Sp, Spitsbergen; CA, Canadian Arctic (Sverdrup Basin); EA, eastern Alaska; S, Stikine terrane (western British Columbia); EK, Eastern Klamath terrane (northern California); Mo, Morroco; NC, North China; SC, South China; TM, Tarim; Tr, Taurides, Turkey; SS, Sanandaj-Sirjan; Alb, Alborz; T, Tabas; cA, Central Afghanistan; Tib, Tibat; Sibumasu, Siam-Burma-Malaya-Sumatra, Asu, Australia.

2012), Klamath mountains, in NW California, the Alexander terrane and Brooks Range in southeastern Alaska (Armstrong, 1972, Fedorowski \& Stevens, 2014). Furthermore, based on their generic level, composition of the Central Iran colonial corals including Heritschioides, Minatoa and Kleopatrina (porfirievella) bashkirica mentioned by Flügel $(1974,1994)$ and Badpa et al. (2011, 2014), show a close affinity between Iranian fauna and those of the Northern provinces of Urals, Novaya Zemlja (Gorsky, 1938, 1951, Fedorowski \& Stevens, 2014), the Kuiu Island area and Brooks Range, Alaska (Armstrong, 1972, Fedorowski \& Stevens, 2014, Fedorowski et al., 2014) (Figure 14).

The faunal similarities between the South West of Paleotethys's corals association with coeval biota in the Arctic could be due to continuity of tropical warm water conditions in the northern hemisphere and connection with south western of Paleotethys ocean during the Bashkirian. The studies carried out on fossil groups other than corals, such as brachiopods by Angiolini et al. (2007), foraminifera (Leven \& Gorgij, 2006), crinoids (Webster et al., 2003) and palynomorphs (Angiolini \& Stephenson, 2007), indicate that the late Carboniferous-early Permian Iranian fauna is similar to coeval biota from the warm Boreal Realm (Shi, 1998; Fedorowski et al., 2007) of the Arctic and Urals (Figure 14). The findings of the present study gives an idea for late Carboniferous corals' evolution and larval migration that lived in the northern margin of the Gondwana.

\section{CONCLUSION}

There are an assemblage of Fasciculate Kleopatrinid rugose corals in the Bashkirian of East Central Iran (Ozbakkuh Mnts.); belonging to the genera Fomichevella including a new species $F$. najafi sp. nov., Heintzella comprising of a new species $H$. fluegeli sp. nov. and Paraheritschioides. It is the first time that Heintzella is reported from Iran. Based on their generic level, the composition of the Central Iran colonial corals show a close affinity between Iranian fauna and those of the Northern provinces of Urals, Novaya Zemlja, the Kuiu Island area and Brooks Range, Alaska. The Iranian species of Paraheritschioides in the present study represents the oldest known occurrence of that genus in the world.

\section{ACKNOWLEDGEMENTS}

The first author was benefited by financial supports from E. Poty. We sincerely thank him and the staff of the Service de Paléontologie animale et humaine, Département de Géologie, Université de Liège, Belgium. The authors acknowledge J. Fedorowski, C. Stevens and especially J. Denayer who provided us constructive remarks on the early version of the manuscript and stimulating discussions on the systematics; S. Rodriguez, V. Ogar, O. Kossovaya, I. Somerville and E.W. Bamber are thanked for their helpful comments and advice.

\section{REFERENCES}

Aghabanati, S.A. 1977. Etude géologique de la région de Kalmard. Tehran, Geological Survey of Iran, 230 p. (Report 35).

Aghanabati, A. 2004. Geology of Iran. Tehran, Geological Survey of Iran, 586 p. [in Persian].

Aghanabati, A. 2009. Stratigraphic Lexicon of Iran. Tehran, Geological Survey of Iran, 664 p. [in Persian].

Angiolini, L.; Gaetani, M.; Muttoni, G.; Stephenson, M.H. \& Zanchi, A. 2007. Tethyan oceanic currents and climate gradients 300 m.y. ago. Geology, 35:1071-1074. doi:10.1130/G24031A.1

Angiolini, L. \& Stephenson, M.H. 2007. Early Permian brachiopods and palynomorphs from the Dorud Formation (Alborz Mountains, northern Iran): evidence for their palaeobiogeographic affinities. Fossils and Strata, 37:34-67.

Armstrong, A.K. 1972. Pennsylvanian carbonates, paleoecology and rugose colonial corals, north flank, eastern Brooks Range, arctic Alaska. USGS Professional Paper, 747:1-21.

Badpa, M.; Ashouri, A. \& Khaksar, K. 2011. The study of late Serpukhovian/Early Namurian corals of Sardar Formation in Zeludu section, Ozbak Kuh mountains (Eastern Central Iran). Sedimentary Facies, 4:1-10. [in Persian with English summary].

Badpa, M.; Khaksar, K.; Ashouri, A. \& Khanehbad, M. 2014. Bashkirian corals (Late Carboniferous) of Sardar Formation in Zaladu section, Ozbak-Kuh mountains, East Central Iran. Journal of Stratigraphy and Sedimentology Researches, 30:3958. [In Persian with English summary].

Bagheri, S. \& Stampfli, G.M. 2008. The Anarak, Jandaq and Posht-eBadam metamorphic complexes in central Iran: new geological data, relationships and tectonic implications. Tectonophysics, 451:123-155. doi:10.1016/j.tecto.2007.11.047

Boncheva, I.; Bahrami, A.; Yazdi, M. \& Torabi, H. 2007. Carboniferous conodont biostratigraphy and Late Paleozoic 
depositional evolution in South Central Iran (Asadabad section, SE Isfahan). Rivista Italiana di Paleontologia e Stratigrafia, 113:329-356.

Brunet, M.F.; Wilmsen, M. \& Granath, J.W. 2009. South Caspian to Central Iran Basins. London, Geological Society, 352 p. (Special Publications 312).

Dobrolyubova, T.A. 1936. Rugose corals of the Middle and Upper Carboniferous and Lower Permian of the northern Urals. Trudy Polyarnoi Komissii, Akademiya Nauk SSSR, 28:77-158. [In Russian].

Dubatolov, V.N. \& Vassiljuk, N.P. 1980. Coral paleozoogeography in the Devonian and Carboniferous of Eurasia. Acta Palaeontologica Polonica, 25:519-529.

Fedorowski, J. 1964. On the Late Palaeozoic Rugosa from Hornsund, Vestspitsbergen. Studia Geologica Polonica, 11:139-146.

Fedorowski, J. 1965. Lower Permian Tetracoralla of Hornsund, Vestspitsbergen. Studia Geologica Polonica, 17:1-173.

Fedorowski, J. 1967. The Lower Permian Tetracoralla and Tabulata from Treskelodden, Vestpitsbergen. Norsk Polarinstitutt Skrifter, 142:5-44.

Fedorowski, J. 1975. On some Upper Carboniferous Coelenterata from Bjornoya and Spitsbergen. Acta Palaeontologica Polonica, 25:27-78.

Fedorowski, J. 1981. Carboniferous corals: distribution and sequence. Acta Palaeontologica Polonica, 26:87-160.

Fedorowski, J. 2004. Considerations on most Rugosa and the Dividocorallia from de Groot (1963) collection. Scripta Geologica, 127:71-311.

Fedorowski, J. 2009a. Early Bashkirian Rugosa (Anthozoa) from the Donets Basin, Ukraine. Part 1. Introductory considerations and the genus Rotiphyllum Hudson, 1942. Acta Geologica Polonica, 59:1-37.

Fedorowski, J. 2009b. Early Bashkirian Rugosa (Anthozoa) from the Donets Basin, Ukraine. Part 2. On the genera Axisvacuus gen. nov. and Falsiamplexus Fedorowski, 1987. Acta Geologica Polonica, 59:283-317.

Fedorowski, J.; Bamber, E. \& Baranova, D.V. 2012. An unusual occurrence of Bashkirian (Pennsylvanian) rugose corals from the Sverdrup Basin, Arctic Canada. Journal of Paleontology, 86:979-995. doi: 10.1666/11-144R1.1

Fedorowski, J.; Bamber, E. \& Stevens, H. 2007. Lower Permian colonial rugose corals, Western and Northwestern Pangaea, taxonomy and distribution. Ottawa, NRC Research Press, $231 \mathrm{p}$.

Fedorowski, J.; Bamber, E.W. \& Stevens, C.H. 2014a. A revision of Heritschioides Yabe, 1950 (Anthozoa, Rugosa), latest Mississippian and earliest Pennsylvanian of western North America. Palaeontologia Electronica, 17:11A.

Fedorowski, J. \& Ogar, V.V. 2013. Early Bashkirian Rugosa (Anthozoa) from the Donets Basin, Ukraine. Part 4.Cordibia, a new protocolonial genus. Acta Geologica Polonica, 63:297-314. doi:10.2478/agp-2013-0014

Fedorowski, J. \& Stevens, C.H. 2014. Late Carboniferous colonial Rugosa (Anthozoa) from Alaska. Geologica Acta, 12:239-267. doi:10.1344/GeologicaActa2014.12.3.6

Fedorowski, J.; Stevens, C.H. \& Katvala, E. 2014b. New Late Carboniferous Heritschioidinae (Rugosa) from the Kuiu Island area and Brooks Range, Alaska. Geologica Acta, 12:29-52. doi:10.1344/105.000002074

Fedorowski, J. \& Vassiljuk, N.P. 2011. Early Bashkirian Rugosa (Anthozoa) from the Donets Basin, Ukraine. Part 3. On the genera Cyathaxonia Michelin, 1847 and Barytichisma Moore and Jeffords, 1945. Acta Geologica Polonica, 61:133-152.
Flügel, H.W. 1974. Minatoa, eine neue Rugosengattung aus der Sadar II-Formation (Bashkirium) Ostirans. Archiv für Lagerstättenforschung in den Ostalpen, 2:95-107.

Flügel, H.W. 1975. Zwei neue korallen der Sardar-Formation (Karbon) Ost-Irans. Mitteilungen der Abteilung Geologie Paläontologie und Bergbau am Joanneum, 35:45-53.

Flügel, H.W. 1994. Rugosa aus dem Karbon der Ozbak-Kuh-Gruppe Ost-Irans (Teil 2: Korallen des Sadar II-Member, Bashkirium). Jahrbuch des Geologischen Bundesanstalt, 137:599-616.

Fontaine, H.; Bin Amnan, I. \& Vachard, D. 2003. Carboniferous corals from the Kuantan area, Peninsular Malaysia and associated microfauna: peculiar faunas for Southeast Asia and puzzling faunas for stratigraphy. Minerals and Geological Department Malaysia Technical Papers, 2:69-99.

García -Bellido, D.C. \& Rodríguez, S. 2005. Palaeobiogeographical relationships of poriferan and coral assemblages during the late Carboniferous and the closure of the western Palaeotethys Sea-Panthalassan Ocean connection. Palaeogeography, Palaeoclimatology, Palaeoecology, 219:321-331. doi:10.1016/j. palaeo.2005.01.004

Gorsky, I.I. 1938. Carboniferous corals of Novaya Zemlya. Trudy Vsesoyuznyi Arkticheskogo Instituta, 93:1-221. [In Russian].

Gorsky, I.I. 1951. Carboniferous and Permian corals of Novaya Zemlya. Trudy Nauchno-issledovatel 'skogo Instituta Geologii Arktiki, 32:1-168. [In Russian].

Hill, D. 1981. Supplement 1, Rugosa and Tabulata. In: C. Teichert (ed.) Treatise on Invertebrate Paleontology, Part F, Coelenterata, Geological Society of America and University of Kansas Press, 762 p.

Holtedahl, O. 1913. Zur Kenntins der Karbonagerungen des Westlichen Spitzbergens, 2. Allgemeine stratigraphische und tektonische Beobachtungen. Videnskapsselskapets Skrifter, 23:1-91.

Jenny, J.; Jenny-Deshusses, C.; Stampfli, G. \& Lys, M. 1978. La Formation de Gheselghaleh, nouvelle unité lihtologique du Carbonifère de 1'Elbourz oriental (Iran). Eclogae Geologia Helvetica, 71:297-312.

Jenny, J. \& Stampfli, G. 1978. Lithostratigraphie du Permien de l'Elbourz oriental en Iran. Eclogae Geologiae Helvetiae, 71:551-580.

Khanehbad, M. 2012. The depositional environment, diagenesis and geochemistry of Carboniferous sediment, east-central Iran. Unpublished PhD Thesis, Ferdowsi University of Mashhad, Iran, 247 p. (in Persian with English summary).

Kossovaya, O.L. 1996. The Mid-Carboniferous Rugose coral recovery. In: M.B. Hart (ed.) Biotic recovery from mass extinction events, London, Geological Society, p. 187-199 (Special Publication 102).

Kossovaya, O.L. 2002. Biostratigraphy of the Bashkirian and Moscovian stages of the European part of Russia based on rugose corals. Stratigraphy and paleogeography of the Carboniferous of Eurasia., Uralina Branch of the Russian Academy of Science, p. 167-177. [In Russian with English summary].

Kozyreva, T.A. 1978. The new Carboniferous genus Protodurhamina (Rugosa) anda its role in the phylogeny of the durhaminids. Akademiya Nauk SSSR, Paleontologicheskii Zhurnal, 1:20-24. [in Russian].

Lasemi, Y. 2001. Facies analysis, depositional environments and sequence stratigraphy of the Upper Precambrian and Paleozoic rocks of Iran. Tehran, Geological Survey of Iran, 180 p. [in Persian].

Leven, E.J.; Davydov, V.I. \& Gorgij, M.N. 2006. Pennsylvanian stratigraphy and fusulinids of central and eastern Iran. Palaeontologia Electronica, 1A. 
Leven, E.J. \& Gorgij, M.N. 2011. Fusulinids and Stratigraphy of the Carboniferous and Permian in Iran. Stratigraphy and Geological Correlation, 19:687-776. doi:10.1134/S0869593811070021

Milne Edwards, H. \& Haime, J. 1850. A monograph of the British fossil corals. Part 1. London, Palaeontographical Society, $77 \mathrm{p}$.

Ogar, V.V. 1985. Rugose corals from the Middle Carboniferous and detailed subdivisions of the Bashkirian and Moscovian stages in Gornaya Bashkiria. Ph.D. thesis, 27 p. [In Russian].

Ogar, V.V. 1990. The characteristics of the stratigraphical distributions of corals in the middle Carboniferous of Bashkiria; boundaries of biostratigraphical subdivisions of the Carboniferous of the Urals. Sverdlovsk, Uralian branch of Academy of Science of USSR, p. 109-119. [In Russian]

Rodríguez, S. 1984. Corales Rugosos del Carbonifero del Este de Asturias. Universidad Compulutense de Madrid, Ph.D. thesis, 528 p.

Rodríguez, S.; Somerville, I.D.; Said, I. \& Cozar, P. 2013. Mississippian-like rugose corals from a Bashkirian biostrome in the Tindouf Basin, S. Morocco. Spanish Journal of Palaeontology, 28:253-282.

Ruttner, A.; Nabavi, M.H. \& Alavi, M. 1970. Geological map of the Ozbak-kuh mountain 1:100,000.

Sando, W.J. 1985. Paraheritschioides, a new rugose coral genus from the Upper Pennsylvanian of Idaho. Journal of Paleontology, 59:979-985.

Scotese, C.R. \& Langford, R.P. 1995. Pangea and the paleogeography of the Permian. In: P.A. Scholle; T.M. Peryt \& D.S. UlmerScholle (eds.) The Permian of Northern Pangea, SpringerVerlag, p. 3-19. doi:10.1007/978-3-642-78593-1_1

Semenoff-Tian-Chansky, P. 1974. Recherches sur les Tétracoralliaires du Carbonifére du Sahara Occidental. Paris, Centre Nationale de la Recherche Scientifiqu, p. 1-316 (Science de la Terre 30).

Sengor, A.M.C. 1984. The Cimmeride orogenic system and the tectonics of Eurasia. Boulder, Geological Society of America, 82 p. (Special Paper 195).

Shi, G.R. 1998. Aspects of Permian marine biogeography: a review of nomenclature and evolutionary patterns, with particular reference to the Asian Western Pacific Region. Paleoworld, 9:97-112.

Sohrabi, Z. 2005. Biostratigraphy of the Carboniferous (Sardar Formation) - Permian (Jamal Formation) System, in Ozbakkuh area (Zeludu section), based on Foraminifera and Special attitude of Conodonta. Tehran, Geological Survey of Iran, 241 p.

Stampfli, G. \& Pillevuit, A. 1993. An alternative Permo-Triassic reconstruction of the kinematics of the Teyhan realm. In: J. Dercourt; L.E. Ricous \& B. Vrielynck (eds.) Atlas Tethys Paleoenvironmental maps, G. Villars, p. 55-62.

Stepanov, D.L. 1971. Carboniferous Stratigraphy of Iran. Comptes-rendus du Congrès International de Stratigraphie du Carbonifère, 4:1505-1518.

Stevens, C. 2012. Distribution and diversity of Carboniferous and Permian colonial rugose coral faunas in Western North America: clues for placement of allochthonous terranes. Geosciences, 2:42-63. doi:10.3390/geosciences 2020042
Stöcklin, J.; Eftekhar-Nezhad, J. \& Hushmand-Zadeh, A. 1965. Geology of the Shotori Range (Tabas area, East Iran). Tehran, Geological Survey of Iran, 68 p. (Report 3).

Verrill, A.E. 1865. Classification of polyps (extract condensed from a synopsis of the polypi of the North Pacific Exploring Expedition, under Captians Ringgold and Rodgers, U.S.N.). Proceedings of the Essex Institute, 4:145-149.

Webster, G.D.; Maples, C.G.; Mawson, R. \& Dastanpour, M. 2003. A cladid-dominated Early Mississippian crinoid and conodont fauna from Kerman Province, Iran and revision of the Glossocrinids and Rhenocrinids. Journal of Paleontology, 77:1-36. doi:10.1666/0022-3360(2003)77[1:ACEMCA]2.0.CO;2

Weddige, K. 1984. Externally controlled Late Paleozoic events of the Iran Plate. Neues Jahrbuch für Geologie und Paläontologie, 168:278-286.

Wendt, J.; Kaufmann, B.; Belka, Z.; Farsan, N. \& Karimi Bavandpur, A. 2002. Devonian/Lower Carboniferous stratigraphy, facies patterns and palaeogeography of Iran. Part I. Southeastern Iran. Acta Geologica Polonica, 52:129-168.

Wendt, J.; Kaufmann, B.; Belka, Z.; Farsan, N. \& Karimi Bavandpur, A. 2005. Devonian/Lower Carboniferous stratigraphy, facies patterns and palaeogeography of Iran. Part II. Northern and central Iran. Acta Geologica Polonica, 55:31-97.

White, C.A. 1875. Report upon the invertebrate fossils collected in portion of Nevada, Utah, Colorado, New Mexico and Arizona by parties of the expeditions of 1871, 1872, 1873 and 1874. Washington, Report upon United State Geographical Surveys, Government Printing Office, 314 p.

Wilmsen, M.; Fürsich, F.T.; Seyed-Emami, K.M.; Majidifard, R. \& Zamani Pedram, M. 2010. Facies analysis of a large-scale Jurassic shelf-lagoon: the Kamar-e-Mehdi Formation of eastcentral Iran. Facies, 56:59-87. doi:10.1007/s10347-009-0190-8

Wu, W.S. \& Zhao, J.M. 1989. Carboniferous and Early Permian Rugosa from western Guizhou and eastern Yunnan, southwestern China. Palaeontologia Sinica, 177:1-230.

Zhang, Y.L.; Gong, E.P.; Wilson, M.A.; Guan, C.Q. \& Sun, B.L. 2010. A large coral reef in the Pennsylvanian of Ziyun County, Guizhou (South China): the substrate and initial colonization environment of reef-building corals. Journal of Asian Earth Sciences, 37:335-349. doi:10.1016/j.jseaes.2009.09.002

Zhang, Y.L.; Gong, E.P.; Wilson, M.A.; Guan, C.Q.; Sun, B.L. \& Chang, H.L. 2009. Paleoecology of a Pennsylvanian encrusting colonial rugose coral in south Guizhou, China. Palaeogeography, Palaeoclimatology, Palaeoecology, 280:507-516. doi:10.1016/j. palaeo.2009.07.004

Zhu, Z.G. \& Zhao, J.M. 1992. Late Carboniferous and earliest Permian rugose corals from Jiangxi. Acta Palaeontologica Sinica, 31:657-677.

Received in June, 2015; accepted in May, 2016. 